$$
\text { Pontifícia } \text { Universidade }_{\text {Do Rio de Janeiro }}
$$

Bianca Gomes Soares Gonçalves de Mendonça

\title{
Experiência Logística da Marinha do Brasil em Ações Humanitárias: \\ Terremotos no Haiti e no Chile em 2010
}

\section{Dissertação de Mestrado}

Dissertação apresentada ao Programa de Pós-graduação em Engenharia Industrial da PUC-Rio como requisito parcial para obtenção do grau de Mestre em Engenharia de Produção.

Orientadora: Profa. Adriana Leiras

Co-orientador: Prof. Abdon Baptista de Paula Filho 


\title{
Bianca Gomes Soares Gonçalves de Mendonça
}

\section{Experiência Logística da Marinha do Brasil em Ações \\ Humanitárias: \\ Terremotos no Haiti e no Chile em 2010}

\begin{abstract}
Dissertação apresentada como requisito parcial para obtenção do grau de Mestre (opção profissional) pelo Programa de Pós-Graduação em Engenharia de Produção da PUC-Rio. Aprovada pela Comissão Examinadora abaixo assinada.
\end{abstract}

Profa. Adriana Leiras

Orientador

Departamento de Engenharia Industrial - PUC-Rio

Prof. Abdon Baptista de Paula Filho

Co-orientador

Pesquisador Autônomo

Prof. Hugo Miguel Varela Repolho Departamento de Engenharia Industrial - PUC-Rio

Prof. José Roberto de Souza Blaschek Coordenação Central de Extensão - PUC-Rio

Prof. Márcio da Silveira Carvalho

Coordenador Setorial do Centro Técnico Científico - PUC-Rio

Rio de Janeiro, 03 de abril de 2017. 
Todos os direitos reservados. É proibida a reprodução total ou parcial do trabalho sem autorização da universidade, da autora e da orientadora.

\section{Bianca Gomes Soares Gonçalves de Mendonça}

Graduada em Ciências Econômicas pela Universidade Federal Rural do Rio de Janeiro em 2000. Pós-Graduada, no Curso de Aperfeiçoamento para Oficiais Intendentes, pelo Centro de Instrução Almirante Wandenkolk, em 2005; e no Curso de Estado-Maior para Oficiais Intermediários em 2010. Cursou o Mestrado Profissional em Logística entre os anos 2014-2016 na PUC-Rio. Atualmente é Capitão de Corveta do Corpo de Intendentes da Marinha desempenhando funções em operações de previsão de demanda, obtenção, gestão de estoques e tomada de decisão.

Ficha Catalográfica

Mendonça, Bianca Gomes Soares Gonçalves de

Experiência Logística da Marinha do Brasil em Ações Humanitárias: Terremotos no Haiti e no Chile em 2010 / Bianca Gomes Soares Gonçalves de Mendonça; orientadora: Adriana Leiras; co-orientador: Abdon Baptista de Paula Filho. $-2017$.

$$
87 \mathrm{f} . ; 30 \mathrm{~cm}
$$

Dissertação (mestrado) - Pontifícia Universidade Católica do Rio de Janeiro, Departamento de Engenharia Industrial, 2017.

Inclui bibliografia

1. Engenharia Industrial - Teses. 2. Logística. 3. Logística militar. 4. Ações humanitárias. 5. Abastecimento. 6. Marinha do Brasil. I. Leiras, Adriana. II. Paula Filho, Abdon Baptista de. III. Pontifícia Universidade Católica do Rio de Janeiro. Departamento de Engenharia Industrial. IV. Título.

CDD: 658.5 


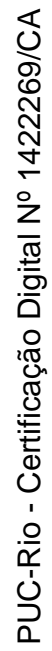

Aos meus amados, Emílio e Laura, por todo o amor, confiança e apoio. 


\section{Agradecimentos}

A Deus, por me permitir ter saúde para superar o desafio imposto e as dificuldades que surgiram ao longo do caminho.

Ao meu pai (in memorian) e minha mãe, pois sem o alicerce que eles me proporcionaram, este trabalho não seria possível.

À Marinha do Brasil, por conceder-me a oportunidade.

Ao Vice Almirante (IM) Helio Mourinho Garcia Junior, agradeço o exemplo e todo o ensinamento.

À minha orientadora, Professora Adriana Leiras.

Ao Professor Abdon Haddad, agradeço pelos ensinamentos, paciência, compreensão, contribuições valiosas e disponibilidade para a realização deste trabalho.

Aos Professores do Departamento de Engenharia Industrial, da PUC-RJ.

Aos meus colegas de Mestrado pelo companheirismo e bons momentos vividos.

À minha querida colega de curso, Heloísa Pinzon, sempre disposta a me ajudar, tornando possível a conclusão deste trabalho.

Ao meu amigo Filipe Pereira Carvalho, pelo apoio.

Aos meus tesouros, Emilio e Laura, pelo amor e apoio incondicional, cuidado para comigo, compreensão pelos momentos de ausência, e pela confiança. Sem vocês, eu não teria conseguido. Amo vocês!!!! 


\section{Resumo}

Mendonça, Bianca Gomes Soares Gonçalves de; Leiras, Adriana (Orientadora); Paula Filho, Abdon Baptista de (Co-orientador). Experiência Logística da Marinha do Brasil em Ações Humanitárias: Terremotos no Haiti e no Chile em 2010. Rio de Janeiro, 2017. 87p. Dissertação de Mestrado - Departamento de Engenharia Industrial, Pontifícia Universidade Católica do Rio de Janeiro.

A assistência humanitária em casos de desastres vem desempenhando papel significativo nos estudos da logística atualmente. Neste cenário, onde a participação de militares brasileiros prestando este tipo de assistência tem sido cada vez mais marcante, cabe às instituições que compõem as Forças Armadas brasileiras revisar, documentar e analisar continuamente os processos e métodos quando atuando em assistência humanitária. Este trabalho tem como objetivo apresentar os obstáculos que a Marinha do Brasil encontrou e como foi sua atuação no campo logístico quando participou de ações humanitárias nos terremotos ocorridos no Haiti e no Chile, ambos no ano de 2010. A contribuição desta pesquisa é principalmente servir de fonte documental retratando como foi o apoio prestado pelos militares na época que os eventos ocorreram e a sistemática de abastecimento atualmente empregada pela Força, visando melhorar as decisões a serem tomadas na Marinha do Brasil, quando esta se deparar com casos semelhantes aos que aqui foram tratados. A metodologia de pesquisa utilizada foi de abordagem qualitativa, com objetivo exploratório e descritivo, por meio de pesquisa bibliográfica em conceitos presentes no ramo da logística e em doutrinas legais que regem a logística militar. O estudo de caso pautou-se em apresentar dois eventos e analisar a atuação da Marinha em cada um deles. A revisão e análise dos casos aqui tratados resulta no apoio a novos estudos que visem o aperfeiçoamento de processos e o melhor gerenciamento de cadeias logísticas que sejam capazes de aliviar o sofrimento humano por meio de operações humanitárias.

\section{Palavras-chave}

Logística; logística militar; ações humanitárias; abastecimento; Marinha do Brasil; Haiti; Chile. 


\section{Abstract}

Mendonça, Bianca Gomes Soares Gonçalves de; Leiras, Adriana (Advisor); Paula Filho, Abdon Baptista de (Co-advisor). Logistic experience of the Brazilian Navy in humanitarian actions: earthquakes in Haiti and Chile in 2010. Rio de Janeiro, 2017. 87p. Dissertação de Mestrado - Departamento de Engenharia Industrial, Pontifícia Universidade Católica do Rio de Janeiro.

Humanitarian assistance for disaster events has been playing a significant role in logistics studies nowadays. In this scenario, where the participation of Brazilian military personnel proving this type of assistance has been increasingly important, it is duty of the institutions that compose the Brazilian Armed Forces to continuously review, document and analyze the processes and methods when acting in humanitarian assistance. This dissertation aims to present the obstacles that the Brazilian Navy encountered and how it performed in the logistic field when it participated in humanitarian actions after the earthquakes in Haiti and Chile, both in the year of 2010. The contribution of this research is mainly to serve as a documentary source, depicting the support provided by the military at the time the events occurred and the supply system currently employed by the Force, aiming to improve the decisions to be taken in the Brazilian Navy, when it faces similar cases in the future. The research methodology used was a qualitative approach, with an exploratory and descriptive objective, through a bibliographical research on concepts present in the logistics sector and in legal doctrines that govern the military logistics. The case study consisted in presenting two events and analyzing the Brazilian Navy`s performance in each of them. The review and analysis of the cases discussed here results in support for further studies that aim the improvement of processes and the better managing of logistics chains that are capable of alleviating human suffering through humanitarian operations.

\section{Keywords}

Logistics; Military logistics; Humanitarian actions; supply; Brazilian Navy; Haiti; Chile. 


\section{Sumário}

1. Introdução 14

1.1. Objeto de estudo e objetivos de pesquisa 17

1.2. Contribuição 19

1.3. Estrutura da dissertação 20

$\begin{array}{lr}\text { 2. Metodologia de pesquisa } & 21\end{array}$

3. Revisão bibliográfica $\quad 24$

3.1. Gestão de stakeholders $\quad 24$

3.2. Logística 26

3.2.1. Logística militar $\quad 29$

3.3. Desastres 31

3.4. Militares e a assistência humanitária 33

3.5. Características da cadeia humanitária 34

4. Logística da Marinha do Brasil $\quad 37$

4.1. Logística Militar no Brasil 37

4.1.1. Doutrina logística da Marinha 38

4.2. Documentos condicionantes da logística na Marinha do Brasil 41

4.3. Definição de ciclo logístico na Marinha 43

4.4. Tratamento da atividade do abastecimento dentro da logística da Marinha 47

4.5. Execução da logística humanitária na Marinha e suas funções 51

5. Atuação da Marinha do Brasil em operações humanitárias - os casos dos terremotos no Haiti e no Chile em 2010

5.1. A aplicação da doutrina logística pela Marinha do Brasil 54

5.2. Terremoto no Haiti em 2010

5.2.1. Análise da atuação e dificuldades encontradas no Haiti 62

5.3. Terremoto no Chile em $2010 \quad 67$

5.3.1. Análise da atuação e dificuldades encontradas no Chile 71

5.4. Comparativo entre os dois eventos 72

5.5. Desafios a serem superados e lições aprendidas 74

$\begin{array}{ll}\text { 6. Conclusões } & 77\end{array}$

7. Referências bibliográficas $\quad 81$ 


\section{Lista de Figuras}

Figura 1 - Atores da rede de abastecimento de ajuda humanitária

Figura 2 - Cadeia humanitária de suprimento

Figura 3 - Ciclo logístico na Marinha

44

Figura 4 - Intensidade do tremor nas áreas atingidas do Haiti pelo terremoto de 2010

Figura 5 - Intensidade do tremor nas áreas atingidas do Chile pelo terremoto de 2010 


\section{Lista de Tabelas}

$\begin{array}{ll}\text { Tabela } 1 \text { - Tipologia de desastres } & 31\end{array}$

Tabela 2 - Atividades realizadas por militares em ações Humanitárias 34

Tabela 3 - Resumo de danos e perdas no terremoto de 27 de Fevereiro de 2010 - Haiti

Tabela 4 - Resumo de danos e perdas no terremoto de 27 de Fevereiro de 2010 - Chile

Tabela 5 - Comparação entre os dois eventos 


\section{Siglas}

CCIM - Centro de Controle de Inventários da Marinha

CCSM - Centro de Comunicação Social da Marinha

CGCFN - Comando Geral do corpo de Fuzileiros Navais

CNBE - Comissão Naval Brasileira na Europa

CNBW - Comissão Naval Brasileira em Washington

ComOpNav - Comando de Operações Navais

COMRJ - Centro de Obtenção da Marinha do Rio de Janeiro

CSCMP - Council of Supply Chain Management Professionals

DABM - Diretoria de Abastecimento da Marinha

DBM - Doutrina Básica da Marinha

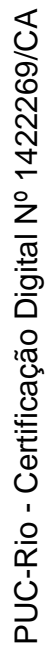

DGPM - Diretoria Geral do Pessoal da Marinha

DIPLAB - Diretiva de Planejamento do Abastecimento da Marinha

DoD - Department of Defense

EGN - Escola de Guerra Naval

EMA - Estado Maior da Armada

ESG - Escola Superior de Guerra

EUA - Estados Unidos da América

EVAM - Evacuação Aeromédica

FAB - Força Aérea Brasileira

FEMA - Federal Emergency Management Agency

GHA - Global Humanitarian Assistance

GRH - Government of the Republic of Haiti

HCamp - Hospital de Campanha

KM - Quilômetros

LBDN - Livro Branco de Defesa Nacional

MB - Marinha do Brasil

MD - Ministério da Defesa

MINUSTAH - Missão das Nações Unidas para a estabilização do Haiti OM - Organização Militar 
ONG - Organização não governamental

ONU - Organização das Nações Unidas

OPAS - Organização Pan-Americana da Saúde

PAHO - Pan American Health Organization

PIB - Produto Interno Bruto

PND - Política Nacional de Defesa

PROA - Prioridade Operativa do Abastecimento

RS - Rio Grande do Sul

SAbM - Sistema de Abastecimento da Marinha

SCM - Supply Chain Management

SW - Sudoeste

TON - Tonelada

USGS - United States Geological Survey

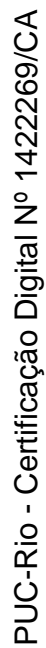

USS - United States Ship

UTI - Unidade de tratamento intensivo 


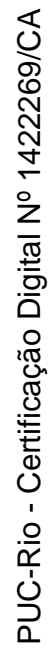

“Na falta de vento, reme." Autor desconhecido 


\section{Introdução}

De acordo com a Estratégia Internacional para a Redução de Desastres das Nações Unidas (ONU, 2009), desastre pode ser definido como:

"uma ruptura grave do funcionamento de uma comunidade ou uma sociedade, envolvendo perdas generalizadas de recursos humanos, materiais, econômicos e ambientais, que excede a capacidade da comunidade ou sociedade afetada, de lidar com seus próprios recursos. Um desastre é o resultado de uma combinação de ameaças, condições de vulnerabilidade e capacidade de medidas insuficientes para reduzir as consequências negativas e potenciais do risco.”

Sendo assim, pode-se dizer que desastres, independentemente de sua origem ou magnitude, são eventos não facilmente administráveis por procedimentos rotineiros, perante os quais se verifica a necessidade de atuação e planejamento conjunto de várias entidades, como órgãos governamentais, setores privados, agências humanitárias e comunidades, em ações preventivas e corretivas de regiões vulneráveis a tais eventos.

As participações de militares em operações humanitárias com sua experiência em resposta a desastres têm desempenhado um relevante papel na prestação de apoio nesses eventos (GHA, 2013). Para Weeks (2007), os militares devem ser resilientes e robustos para lidar com as incertezas do combate e esta resiliência pode ser considerada uma característica bastante útil quando militares são empregados em situações e ambientes afetados por desastres, como foi o caso da atuação de militares norte-americanos no terremoto que ocorreu em 2005 no Paquistão.

Para exemplificar o uso das Forças Armadas brasileiras em casos de assistência humanitária, o Livro Branco de Defesa Nacional - LBDN (Brasil, 2012) traz alguns apoios prestados pelas Forças Armadas, onde se destaca o envolvimento de 1.200 militares no apoio ao socorro das necessidades que surgiram na região serrana do estado do Rio de Janeiro, em janeiro de 2011, por ocasião de enchentes e deslizamentos de terra que atingiram essa região, além de apoios prestados também em 2011, em situações semelhantes às da região serrana, nos estados de Goiás, Paraná, Santa Catarina e Rio Grande do Sul. 
A partir da análise de catástrofes, Philips (2011) identificou fatores determinantes para a eficiência da resposta militar a desastres, dentre os quais pode-se destacar:

- a prontificação dos efetivos;

- a adequação dos recursos utilizados;

- a interoperabilidade dos meios militares com os esforços de ajuda mais ampla, inclusive a internacional, vindos das diferentes organizações envolvidas no esforço de ajuda;

- a capacidade de absorção do país que recebe a ajuda para acomodar um grande fluxo de bens e pessoas; e

- a coordenação entre diversas instituições (civis, militares, governamentais e não governamentais) neste país para de maneira conjunta gerenciar a assistência recebida de culturas organizacionais diferentes.

A destinação primordial das Forças Armadas, em muitos países, é a defesa da pátria, dos interesses nacionais e a manutenção da soberania dos países; porém não é raro que se observe também outras bases legais que amparam a atuação das Forças Armadas, participando de ações no campo humanitário, seja em seu território ou externamente, em países que solicitam tais ações (Aversa, 2011; Artiaga, 2012).

No Brasil, diversas são as bases legais que condicionam a logística militar e como esta deve ser aplicada, permitindo sua utilização em operações humanitárias, são elas: a Constituição Federal de 1988 (Brasil, 1988), a Lei Complementar $n^{\circ}$ 97/1999 (Brasil, 1999), a Diretriz Ministerial $n^{\circ}$ 004/2001 (Brasil, 2001), a Política de Logística de Defesa (Brasil, 2006), a Política Nacional de Defesa (Brasil, 2013a), a Doutrina de Logística Militar (Brasil, 2016a), a Estratégia Nacional de Defesa (Brasil, 2013b) e o Livro Branco de Defesa Nacional (Brasil, 2012).

Fazendo-se uma análise das bases legais apresentadas acima, pode-se depreender que a logística desenvolvida nos meios militares brasileiros tem sua atuação na estratégia e na tática de qualquer operação desenvolvida pelas Forças Armadas do país, principalmente quando encaramos que os recursos existentes são limitados para a realização destas operações. 
A participação das Forças Armadas em ações de natureza humanitária, no Brasil tem como aspectos positivos (Marinho, 2014):

- sua mobilidade; $\mathrm{e}$

- a distribuição de várias organizações militares em todo o território nacional.

Estes aspectos conferem flexibilidade às Forças Armadas, o que favorece uma resposta adequada em situações classificadas como de desastres e, se forem utilizadas de forma apropriada, otimizará a resposta exigida pela situação.

Nesse panorama, as Forças Armadas brasileiras também têm a oportunidade de demonstrar seu preparo para realizar ações de ajuda humanitária, pois podem ser consideradas instrumentos possíveis de, em curto prazo, desenvolverem esforços de mitigação dos efeitos causados por desastres, sejam estes de origem natural, ou não, como por exemplo: a atuação nas enchentes ocorridas nos estados de Santa Catarina, no ano de 2008, e do Rio de Janeiro, no ano de 2011, e a Evacuação Aeromédica (EVAM) no incêndio na Boate Kiss, em Santa Maria, RS, no ano de 2013 (Marinho, 2014). Sendo assim, pode-se entender que operações de resposta em casos de desastres podem apresentar melhor eficiência quando a expertise já desenvolvida pela logística utilizada pelas Forças Armadas é aplicada em operações que envolvem de alguma maneira caráter humanitário.

A assistência humanitária internacional posiciona-se como um elemento que contribui para a integração entre os Estados, uma preocupação que se reflete na política externa brasileira, conforme prevê o parágrafo único do artigo $4^{\circ}$ da Constituição Federal: “... o Brasil buscará a integração econômica, política, social e cultural dos povos da América Latina, visando à formação de uma comunidade latino-americana de nações” (Brasil, 1988).

A intensificação nos dias de hoje do uso das Forças Armadas em ações humanitárias tem a capacidade de ampliar a projeção internacional do país, aperfeiçoar e aumentar a capacidade logística das Forças Armadas no exterior, além de ser um exercício da integração e coordenação com outros países, gerando reflexos positivos para a política externa brasileira e internamente fornecendo à sociedade nacional a sensação de que, mesmo em momentos críticos, ela poderá contar com instituições bem estabelecidas, preparadas e dispostas a proporcionar conforto e ambiente seguro até que a normalidade seja minimamente restabelecida, conforme previsto na Política Nacional de Defesa (Brasil, 2013a). 
Para Fontoura (2005), a reconhecida qualidade das atuações das tropas brasileiras em diversos tipos de operações consolida a imagem favorável do Brasil como país capaz de assumir maiores responsabilidades no campo da paz e da segurança internacionais. As ações das tropas brasileiras contribuem positivamente na projeção e interesse do Brasil em prestar solidariedade e auxílio humanitário àquelas nações afetadas por conflito armado ou caos civil/social. Essa tarefa revela a responsabilidade da política externa brasileira.

De acordo com o previsto no Livro Branco de Defesa (Brasil, 2012), a Marinha do Brasil (MB), como órgão integrante das Forças Armadas brasileiras, por meio do emprego de seus meios navais, aeronavais e de fuzileiros navais, busca apresentar as condições necessárias para realizar operações de evacuação de não combatentes, operações de paz e ações humanitárias, projetando uma tropa anfíbia, independentemente do grau de hostilidade e do tipo de missão a ser cumprida.

Para que o emprego dos meios navais, aeronavais e de fuzileiros navais busquem cumprir uma missão estabelecida, o esforço logístico realizado é agrupado em funções logísticas definidas no Manual de Logística da Marinha (Brasil, 2003), que são: Recursos Humanos, Saúde, Suprimento, Manutenção, Engenharia, Transporte e Salvamento.

Aqui, vale ressaltar que, para que a $M B$ se adequasse à Doutrina de Logística Militar (Brasil, 2016a), abastecimento não é definido como função logística, passando a ser entendido em sentido amplo, como um conjunto de atividades voltadas para o apoio de material e serviços necessários às Forças e demais Organizações Militares (OM), englobando a função logística suprimento e parte da função logística transporte, além de relacionar-se estreitamente com a função logística manutenção.

\section{1}

\section{Objeto de estudo e objetivos de pesquisa}

Esta pesquisa apresenta uma análise da atividade logística da Marinha do Brasil e ressalta aspectos relacionados aos processos de abastecimento utilizado em condições normais ou quando a Força é acionada para atuar em missões de 
caráter humanitário, seja participando do socorro de vítimas, seja fornecendo materiais e serviços para que outras organizações atuem nesse socorro.

O objetivo aqui é o de apresentar, por meio de pesquisas documental e bibliográfica realizadas nas diversas bases de dados disponíveis, seja em instituições militares ou civis, os desafios enfrentados pela Marinha do Brasil para que realizasse operações de ajuda humanitária em dois eventos ocorridos recentemente. Sendo assim, o que se busca é apresentar como essas atuações se deram e como foram cumpridas, principalmente no que se refere às competências legais e aos aspectos da gestão logística.

A apresentação considera a doutrina da Marinha em termos de logística e abastecimento, suas principais características, conceitos, desenvolvimentos, aplicação de sistemáticas e dificuldades nos dois eventos, que aqui são tratados.

Para que os obstáculos encontrados na realização do trabalho dos militares sejam identificados, neste estudo, é apresentada a atuação do segmento logístico da Marinha do Brasil em dois desastres ocorridos no ano de 2010 e que foram escolhidos com base na disponibilidade de dados e por serem desastres de mesmo tipo ocorridos na mesma época, mas em locais diferentes que são: o terremoto no Haiti em janeiro de 2010 e o terremoto no Chile em fevereiro de 2010.

A partir do contexto apresentado, os objetivos específicos neste trabalho são:

- apresentar duas participações da Marinha do Brasil em operações de ações de assistência humanitária; e

- apresentar, com base nas doutrinas logísticas que regem a Marinha do Brasil, os aspectos logísticos envolvidos nessas operações.

A abordagem desta pesquisa é qualitativa, procurando apresentar como a logística na Marinha se desenvolve, dentro de um contexto real de casos a serem estudados. Trata-se de uma pesquisa exploratória e descritiva. 


\section{2}

\section{Contribuição}

Atualmente, tem se observado, seja no meio acadêmico civil, seja no meio acadêmico militar, um crescente interesse em se estudar a participação de militares em ações com caráter humanitário. Isso posto, espera-se que os resultados desta pesquisa possam contribuir para o desenvolvimento de novos estudos acadêmicos no tema, além de servir como fonte de pesquisa documental para apoio a futuras ações logísticas, que busquem melhorar as decisões a serem tomadas por aqueles que atuam nas atividades logísticas da Marinha e nas Forças Armadas brasileiras, ou até mesmo externamente a estas, quando as necessidades superarem suas possibilidades, utilizando o poder nacional, o potencial nacional ou facilidades no exterior, de modo contínuo, metódico e permanente durante sua fase de preparo, e de modo acelerado e compulsório por ocasião da iminência ou concretização de atuação em alguma ação de caráter humanitário.

Desse modo, o tema desta pesquisa, que tem como base documentos governamentais e normas vigentes, poderá servir de parâmetro para estudos futuros na Marinha do Brasil e externamente à Força, para definir procedimentos e corrigirem rumos, referentes ao preparo e emprego de tropas em ações de assistência humanitária nacional e internacional, assim como contribuir para a ampliação do intercâmbio entre os bancos de conhecimentos internos às Forças Armadas e o meio acadêmico civil.

Por fim, a principal contribuição pretendida com essa pesquisa é para que ocorra o aperfeiçoamento de processos nas atividades que são realizadas pelos órgãos componentes da logística da Marinha do Brasil, como por exemplo aqueles relacionados a obtenção e armazenagem de material. Este aperfeiçoamento contribui para reduzir o tempo de resposta apresentado, em apoio as operações de ajuda humanitária interferindo, de forma mais positiva, inevitável e oportuna, nos planejamentos a serem realizados pela Força. 


\section{3}

\section{Estrutura da dissertação}

Além deste capítulo introdutório, o trabalho aqui apresentado compreende cinco capítulos. O segundo é a metodologia adotada no trabalho, abordando o tipo de pesquisa e o método adotado. O terceiro capítulo faz uma revisão bibliográfica, apresentando os principais conceitos logísticos relacionados ao tema, aqui abordados: gestão de stakeholders, logística, logística militar, desastres, militares e a assistência humanitária e as características da cadeia humanitária. O quarto capítulo aborda a aplicação da atividade logística na Marinha, com base em seus documentos doutrinários, processos e sistemáticas de abastecimento. O quinto capítulo apresenta os casos aqui estudados e as particularidades da atuação da Marinha do Brasil nestas operações internacionais, de caráter humanitário, os terremotos do Haiti e do Chile, ambos em 2010. São apresentados também neste capítulo, a análise desta atuação e uma comparação entre os dois eventos estudados, assim como as dificuldades encontradas no campo da legislação brasileira e procedimentos intra-Marinha que poderão representar vantagens ou obstáculos logísticos em atuações futuras. O capítulo seis finaliza esta pesquisa, apresentando as conclusões e propostas de estudos futuros. 


\section{2}

\section{Metodologia de pesquisa}

Este capítulo aborda a metodologia de pesquisa utilizada para a realização deste trabalho, que tem seu embasamento numa abordagem qualitativa, pois de acordo com Silveira e Córdova (2009), a pesquisa qualitativa tem uma menor preocupação com representatividade numérica. Seu enfoque está em aprofundar a compreensão de um grupo social ou de uma organização e, no caso aqui apresentado, a compreensão que se aborda é a da atuação logística na Marinha do Brasil em missões humanitárias.

Segundo Yin (2013), o embasamento de uma abordagem qualitativa realizada na forma empírica, investiga um fenômeno contemporâneo inserido num contexto da vida real, principalmente quando os limites entre o fenômeno e o contexto não estão com uma definição bastante clara. Ou seja, neste caso, parte-se de situações reais de desastres ocorridos do Haiti e no Chile em 2010, em que ocorreu a atuação da Marinha do Brasil em operações de caráter humanitário, relacionando a atuação da logística da MB e de seu sistema de abastecimento nestas situações, desde quando a Força é acionada, considerando sua eficiência e eficácia, de acordo com o previsto no Manual de Logística da Marinha do Brasil (Brasil, 2003).

Para alcançar esse propósito, a metodologia adotada engloba descrição, pesquisa, comparação e análise das informações levantadas. Quanto à natureza, classifica-se esta pesquisa como aplicada, de acordo com a classificação proposta por Silveira e Córdova (2009), pois objetiva gerar conhecimentos para aplicação prática, dirigidos à solução de problemas específicos, envolvendo verdades e interesses sociais. Ou seja, a pesquisa aplicada propõe-se a gerar conhecimento que terá aplicabilidade para a solução de um problema específico.

Esta pesquisa, quanto a objetivos classifica-se em exploratória, pois pretende apresentar o problema da aplicação da logística da Marinha em ações de caráter humanitário, e descritiva, pois as informações sobre o que se deseja pesquisar são buscadas dentro de organizações militares e civis que atuam nesses 
processos, sendo por meio de estudos realizados ou trabalhando efetivamente neles.

A estratégia de pesquisa aqui utilizada foi o estudo de caso e conforme apregoa Yin (2013), o estudo de caso permite uma investigação para se preservar as características holísticas e significativas dos eventos da vida real - tais como ciclos de vida individuais, processos organizacionais e administrativos, mudanças ocorridas em regiões urbanas, relações internacionais e a maturação de alguns setores. Ainda de acordo com Yin (2013), as etapas do estudo de caso são: plano, projeto, preparação, coleta de evidências, análise das evidências e relato.

$\mathrm{Na}$ etapa de planejamento foram definidos os eventos ocorridos a serem estudados: os terremotos no Haiti e no Chile, no ano de 2010. Na etapa de projeto foram definidas as publicações para o referencial teórico e doutrinário de acordo com as características dos casos a serem estudados, com enfoque na ação da Marinha do Brasil. Para Cauchick Miguel (2007), a utilização de um referencial teórico serve para mapear a literatura sobre o tema pesquisado, com a devida limitação do que será investigado, oferecendo o suporte teórico para a pesquisa.

Transcorridas as fases de planejamento e projeto, conforme apregoa Yin (2013), é realizada a preparação/coleta de evidências dos casos, por meio do acesso aos documentos que descrevem os casos estudados. Desta forma, o ponto de partida deste estudo é a realização de uma pesquisa bibliográfica e também, uma pesquisa documental. As base de publicações utilizadas para essa pesquisa são as disponíveis para acesso externo e não classificadas com algum tipo de sigilo militar em diversas organizações militares e civis, como: Escola Superior de Guerra (ESG); Escola de Guerra Naval (EGN); Comando de Operações Navais (ComOpNav); Diretoria de Abastecimento da Marinha (DABM); Centro de Controle de Inventários da Marinha (CCIM); Centro de Obtenção da Marinha do Rio de Janeiro (COMRJ); Comissões Navais Brasileiras na Europa e em Washington (CNBE/CNBW), e pesquisas online em bibliotecas de instituições de ensino superior, que possuam informações sobre os eventos aqui estudados. Sendo assim, dentro da estratégia de pesquisa aqui aplicada, é realizada nesta pesquisa a análise dos conhecimentos obtidos na investigação relacionando os conceitos e doutrinas já existentes sobre o assunto e os aspectos relevantes dos casos estudados. 
A técnica de adequação ao padrão foi utilizada para analisar o material coletado. Na adequação ao padrão, um padrão empírico fundamental é comparado com uma base prognóstica. Se os padrões coincidirem, os resultados reforçam a validade interna do estudo de caso (Yin, 2013). Assim, o referencial teórico, (legislação) é comparado com os dados coletados sobre os casos (Haiti e Chile) para identificar as lições aprendidas nos casos.

A etapa de relato é realizada na dissertação apresentada, compartilhando os resultados do estudo de caso.

Pretende-se por meio de revisão da literatura, apresentar conceitos que permitam a realização de novos estudos que busquem a melhoria dos processos que são amplamente utilizados pelo Sistema de Abastecimento da Marinha (SAbM), além de uma melhoria em todo o potencial logístico já existente na instituição, por meio da ampliação da discussão principalmente a nível estratégico, dos conceitos de logística já aplicados e utilizados por todos os órgãos que operam com a logística na Marinha do Brasil. 


\section{3}

\section{Revisão bibliográfica}

Este capítulo apresenta uma revisão dos conceitos relacionados com o tema aqui estudado, detalhando a base conceitual dos aspectos logísticos envolvidos em operações com enfoque humanitário.

\section{1}

\section{Gestão de stakeholders}

O conceito de stakeholders apresenta-se como pessoas ou grupos com interesses ou envolvimento em algo, ou ainda afetadas ou que influenciam de alguma forma em um processo (Freeman, 1984).

De acordo com Freeman (1984), a gestão dos stakeholders deve ser constituída por três níveis de análise:

- Nível racional - mapeamento dos stakeholders: identificar quem são os stackeholders da organização, construir um mapa destes e de seus interesses, levando em consideração problemas como a participação de um stackholder em mais de um grupo de interesse e a evolução/fortalecimento das redes dos grupos de stackeholders com um determinado propósito, que pode ser benéfico ou não para a organização.

- Nível do processo - entendendo o ambiente: observar os procedimentos operacionais padrão da organização e analisar se eles atendem ou, através de pequenas modificações, podem vir a atender os interesses detectados pelo mapa dos stakeholders.

- Nível transacional - interagindo com os stakeholders: entender de que forma a organização negocia/barganha com seus grupos de interesses, quais são os canais de comunicação usados pela empresa e perceber se estão de acordo com o mapa dos grupos de interesse (nível racional) e os procedimentos da empresa (nível do processo). 
Para Fontainha et al. (2017), conforme mostrado na Figura 1, pelo menos dez atores participam da rede que envolve a logística humanitária, divididos em três grupos principais, são eles:

- grupo público: composto por militares, órgãos governamentais e órgãos legislativos e reguladores;

- grupo privado: composto pelo setor privado, fornecedores diretos e mídia; e

- grupo de pessoas: composto pela rede de ajuda internacional, doadores e rede local de ajuda.

Ainda para Fontainha et al. (2017), o ator beneficiário está desvinculado dos demais porém é a sua existência que sintetiza o papel a ser exercido por todos os outros.

Desta maneira, a coordenação dos processos que formam a logística humanitária exige entendimento do envolvimento entre esses atores e se transforma num desafio a ser vencido.

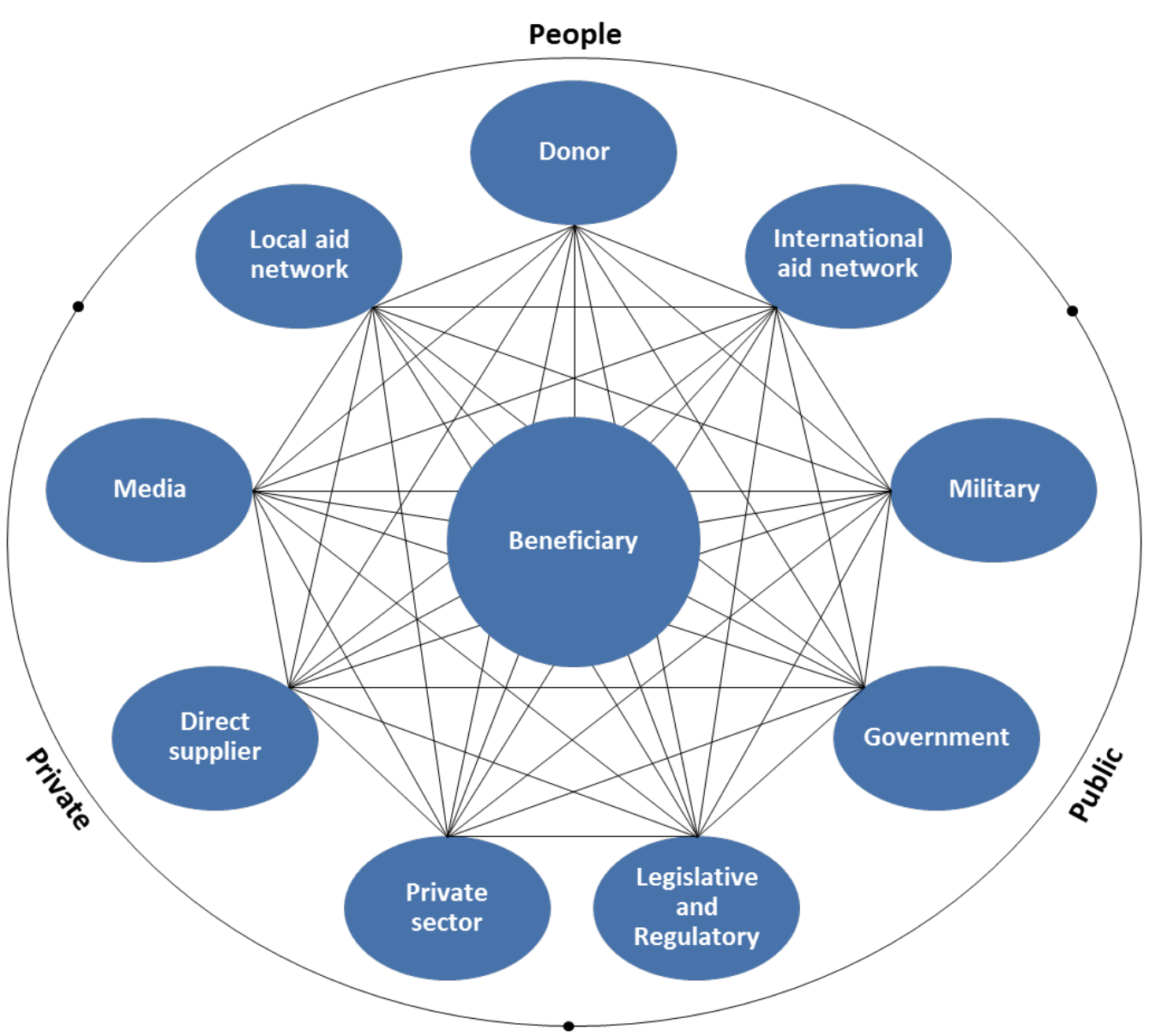

Figura 1: Atores da rede de abastecimento de ajuda humanitária (Fontainha et al., 2017). 
Entende Campbell (1997), que a gestão dos stakeholders deve se utilizar de mecanismos de análise da teoria sistêmica, referente à interdependência e integração dos agentes que compõem um sistema, procurando explicar a interação entre eles.

É comum e esperado que quando a comunidade internacional se depara com a ocorrência de desastres, sejam naturais ou não, essa se mobilize para fazer chegar todo o apoio necessário à região atingida por tal evento e minimizar o sofrimento daqueles que estão sendo atingidos, ou seja, o beneficiário final, a ser considerado também como um agente que participe da rede de ajuda humanitária.

Neste sentido, de acordo com Cazumba (2012), registra-se que a interação de militares, no caso aqui especificamente da Marinha do Brasil agindo em ações humanitárias com outras organizações, pode provocar mudanças nos universos de cada uma destas organizações exigindo um melhor entendimento dos papéis de cada um, assim como a definição de seus campos de atuação e o estabelecimento de regras que oriente o trabalho de cada um dos agentes para que esse ocorra de maneira harmônica em busca do objetivo principal, que é prestar apoio a quem precisa. Internamente, a definição de afazeres nas respectivas esferas de competência e responsabilidade dos que compõem a Marinha do Brasil, também ganha importância na gestão das ações neste tipo de atividade.

\section{2}

\section{Logística}

Está nas obras de dois grandes estudiosos da arte da guerra, Clausewitz (1832) e Jomini (1836), as primeiras referências à logística, no sentido moderno. Para Clausewitz, a arte da guerra dividia-se em dois ramos: a tática e a estratégia, porém, apesar de não tratar especificamente da logística, ele reconheceu que, “ em nossos dias, existe na Guerra um grande número de atividades que a sustentam... mas devem ser consideradas como uma preparação para a mesma”. É a Jomini, contemporâneo de Clausewitz, que se deve pela primeira vez o uso da palavra logística, que a definiu como "a ação que conduz à preparação e sustentação das campanhas", enquadrando-a como “a ciência dos detalhes dentro dos EstadosMaiores”. 
Até a Primeira Guerra Mundial, a palavra logística não se encontrava na literatura; os termos que normalmente se empregava para definir esta atividade era “Administração”, “Organização” e “Economia de Guerra” (Barbosa, 2011). Foi com a publicação do livro "Logística Pura: a ciência da preparação para a guerra”, no ano de 1917, pelo Tenente-Coronel Thorpe, do Corpo de Fuzileiros Navais dos EUA, que a logística passou a ser tratada como ciência. O Coronel Thorpe afirmava que "a estratégia está para a guerra como o enredo está para a peça; a tática é representada pelo desempenho dos artistas; e a logística fornece o cenário, a roupagem, os acessórios e os próprios artistas” (Brasil, 2003). Mas foi na segunda metade do século XX, com o pós Segunda Guerra Mundial, que o conceito de logística passou a ganhar força. Nesta época, os aspectos que envolviam a logística eram tratados de forma isolada entre si e em relação a organização, porém à medida que esta atividade ia ganhando espaço no ambiente organizacional, a integração dela entre as áreas aumentava e o conceito evoluía (Barbosa, 2011).

Novaes (2001) entendeu que a logística podia ser dividida em quatro momentos históricos, de acordo com o modo que esta era aplicada nas organizações. Inicialmente tinha-se uma ação segmentada, na qual os subsistemas eram vistos de forma separada, não havia uma visão de conexão e dependência entre as áreas envolvidas no processo de produção. Num segundo momento, que foi chamado de integração rígida, começou-se a pensar em racionalizar processos, havendo mais planejamento e um maior contato entre as atividades logísticas e as mais próximas destas, mas ainda sem haver uma visão geral da organização. Numa terceira seria empregada a ideia de integração flexível, que se inicia por volta da década de 1980 e com a ajuda da tecnologia vem uma maior flexibilidade entre as relações. E por último, o momento que se vive atualmente, onde ocorre a integração estratégica, que é quando ocorre o gerenciamento da cadeia de suprimentos - Supply Chain Management (SCM), na qual se busca uma visão geral, não apenas dos processos internos, mas também dos processos de relacionamento com os agentes externos da organização.

Para Ching (2010), a cadeia logística de forma integrada pode ser dividida em três partes: a primeira parte é a de suprimentos, que trata do contato entre a empresa e os fornecedores; a segunda parte é a de produção, responsável pelo processamento dos insumos e geração do produto final; e a terceira parte, que trata 
da distribuição, que visa garantir o correto encaminhamento do produto final ao consumidor.

De acordo com o exposto por Ballou (2001), a evolução conceitual de logística permite dizer que sua missão é dispor o produto ou o serviço certo, no lugar certo, no tempo certo e nas condições desejadas, ao mesmo tempo em que fornece maior contribuição a organização.

Para Novaes (2007), o conceito de logística, na sua origem, está essencialmente ligado às operações militares. Porém, é irrefutável que se diga que a evolução destes conceitos, deve-se ao setor empresarial e à comunidade científica.

Em geral, muitos autores adotam como referência, a definição de logística do Council of Supply Chain Management Professionals (2013), apresentada a seguir:

"Logística é o processo de planejar, implementar e controlar de maneira eficiente o fluxo e a armazenagem de produtos, bem como os serviços e informações associados, cobrindo desde o ponto de origem até o ponto de consumo, com o objetivo de atender aos requisitos do consumidor."

Segundo Ching (2010), atualmente a logística perdeu a característica de ser um conjunto de processos, passando a ser vista como algo integrado aos processos das demais áreas de uma instituição, com o objetivo de reduzir custos, otimizar as atividades das organizações e agregar valor ao consumidor final, fatores que aumentam a vantagem competitiva de uma organização.

Diante das definições de logística acima apresentadas, pode-se criar o entendimento de que com a evolução do conceito, esta deixou de ser uma área vista como uma simples operação de transporte e armazenagem de materiais para ser tratada como um enorme componente para a formulação de estratégias mais competitivas das organizações. A logística passou a ser a área que tem a responsabilidade pelo fluxo mais eficiente possível de materiais e serviços.

Para o setor de ajuda humanitária, é importante a percepção de que a logística é formada pelos processos e sistemas envolvidos na mobilização de recursos, habilidades e conhecimento com o objetivo de ajudar comunidades afetadas por situações de emergência, comunidades essas formadas por pessoas vulneráveis que foram afetadas por desastres (Van Wassenhove, 2006). 
Ainda, segundo o autor, quando tratamos de logística para apoiar ações de ajuda humanitária, grandes são os desafios apontados na implementação de processos sistematizados, merecendo destaque os aspectos ligados à infraestrutura, localização de centrais de assistência, coordenação de processos e desenvolvimento de tecnologias, e a logística passa a se desenvolver por meio de processos e sistemas envolvidos na mobilização de recursos, habilidades e conhecimento com o objetivo de ajudar pessoas vulneráveis afetadas por desastres.

\subsection{1}

\section{Logística militar}

A importância da logística entre os militares remonta a épocas muito distantes e desde a antiguidade que estes se utilizam da mesma para definir estratégias de guerras. $\mathrm{Na}$ antiguidade as guerras eram longas e geralmente distantes fazendo-se necessário grandes deslocamentos, onde ficava evidente a necessidade de planejamento, organização e execução de tarefas logísticas.

As diferenças entre a logística empresarial, logística humanitária e logística militar se iniciam em suas metas e objetivos. Para Ballou (2001), a logística empresarial procura reduzir custos, maximizar retorno e melhorar o serviço entregue ao cliente. Já a logística humanitária tem o propósito de salvar vidas e aliviar o sofrimento de pessoas no menor tempo possível, sendo um processo de caráter complexo e altamente instável, pois envolve sérios desafios operacionais. No contexto humanitário, do ponto de vista logístico, faz-se necessário uma operação eficaz e bem coordenada, pois isso pode significar o salvamento de vidas e a diminuição do impacto total do desastre (Varella et al., 2013). Para Kress (2002), quando se trata de logística militar, esta deve ser considerada como uma entidade complexa e multidimensional que se constitui num dos mais importantes e essenciais componentes da guerra. A logística militar apresenta duas dimensões: a primeira se caracteriza por seu lado mais técnico e científico, no qual a regularidade e um certo grau de previsibilidade dos processos possibilita e requer a utilização de ferramentas matemáticas e cálculos estatísticos para amparar as decisões, enquanto a segunda dimensão está ligada à incerteza e à fluidez presente na guerra. 
Entre os meios militares é amplamente difundida a ideia de que, além do grau de sofisticação dos meios tecnológicos utilizados, a logística é um dos pilares estratégicos que possibilitam maiores chances de sucesso em operações (Braz, 2004). É a logística que trata de proporcionar recursos às Forças Armadas e essa se baseia em estimativas de necessidades que permitem a atuação das forças operativas, sendo seu propósito manter a máxima eficiência de combate (Brasil, 2016a).

Segundo a Doutrina Logística americana, descrita em seu Field Manual 4-95 (EUA, 2014), a logística militar pode ser definida como o planejamento e execução do movimento e suporte às tropas, incluindo aspectos das operações militares que lidam com dimensionamento e execução, aquisição, armazenagem, transporte, distribuição, manutenção e disponibilidade do material, aquisição ou construção, manutenção, operação e disposição de instalações, além da aquisição ou fornecimento de serviços.

Sendo assim, de acordo com a Doutrina de Logística Militar (Brasil, 2016a), a estratégia e a tática não podem ser sustentadas sem os recursos proporcionados pela logística, já que, a estratégia determina os objetivos e o método de maneira ampla para atingi-los; a tática determina o emprego específico das forças para alcançar os objetivos traçados pela estratégia; e a logística provê os recursos para apoiar as forças nas necessidades que surjam.

Para Varella et al. (2013), é possível visualizar relações correlatas entre as logísticas militar e humanitária, permitindo elucidar atividades e operações que possam ser trabalhadas em conjunto pelas organizações humanitárias e militares a fim de promover a troca de conhecimento e planejamento.

Especificamente quando se trata da logística militar aplicada na esfera de ajuda humanitária, esta tem se apresentado como um instrumento possível para realizar ações a serem desenvolvidas de forma suficientemente eficiente nos primeiros momentos após a ocorrência de um desastre. A título de exemplo, segundo Elleman (2007), em dezembro de 2004, quando um tsunami matou cerca de 230 mil pessoas em 13 países, desde a Indonésia até o sul da África, a Marinha Americana apoiou com 1,5 milhão de litros de água, 18 milhões de toneladas de gêneros alimentícios e prestação de socorro a milhares de pessoas. Um dos primeiros meios a chegar ao local afetado, em $1^{\circ}$ de janeiro de 2005, foi o PortaAviões USS Abraham Lincoln. 


\section{3}

\section{Desastres}

Os desastres podem ser definidos como o resultado do impacto de fenômenos extremos sobre um sistema social, causando sérios danos e prejuízos que excede a capacidade da comunidade ou da sociedade atingida em conviver com o impacto. Em geral, considera-se como desastre natural todo aquele que tem como gênese um fenômeno natural de grande intensidade, agravado ou não pela atividade humana. Os desastres de origem humana são aqueles resultantes de ações ou omissões humanas e estão relacionados com as atividades do homem, como agente ou autor (Marcelino, 2008).

Outra classificação para desastres encontrada na literatura é a realizada por Van Wassenhove (2006), que propôs uma classificação, de acordo com a origem do impacto causado dividindo-os em desastres naturais (terremotos, tsunamis, furacões, tornados, epidemias, secas, inundações) e desastres causados pelo homem ou também chamados de antropogênicos (atos terroristas, ataques químicos, crises de refugiados e acidentes nucleares) que também podem ser de início repentino e início lento, conforme apresentado na Tabela 1:

Tabela 1: Tipologia de desastres (Van Wassenhove, 2006).

\begin{tabular}{|l|l|l|}
\hline & Natural & Provocado pelo homem \\
\hline \multirow{3}{*}{ Início Repentino } & Terremoto & Ataque terrorista \\
& Furacão & Golpe de Estado \\
& Tornado & Vazamento de produtos químicos \\
\hline \multirow{3}{*}{ Início Lento } & Fome & Crise Política \\
& Seca & Crise de refugiados \\
& Pobreza & \\
\hline
\end{tabular}

Para Long e Wood (1995), desastres classificados como de início repentino, apresentam-se com maior impacto na infraestrutura local e exigem uma maior rapidez na resposta, devido ao impacto propriamente dito e a comoção causada, além da grande exposição na mídia. Neste momento, a relevância das ações está na rapidez com que elas são executadas pelos atores que vão participar destas. Já para os desastres classificados como de início lento, a preparação apresenta uma 
elasticidade de tempo positiva, podendo serem utilizadas estratégias de ações mais elaboradas, mas a comoção e a visibilidade causada, por outro lado, são bem menores.

De acordo com Holguín-Veras et al. (2012), é importante fazer uma distinção entre desastre e catástrofe para determinar as ações logísticas necessárias, já que frente a um desastre as diferentes redes envolvidas são capazes de responder ao provimento com os recursos locais, as cadeias de abastecimento respondem e a distribuição de suprimentos é possível. Já no caso da catástrofe, as redes envolvidas são afetadas fortemente, os suprimentos disponíveis são mínimos, as cadeias de suprimentos do setor privado encontram-se fora de funcionamento por semanas, surge o aumento de demanda de suprimentos básicos e necessita-se de um esforço completo de distribuição para satisfazer às necessidades dos sobreviventes e colaboradores e a maior parte dos suprimentos básicos devem ser trazidos de fora.

Segundo Kobiyama et al. (2006), desastres são fenômenos que exigem ações preventivas e restituidoras e, dependendo do impacto provocado por esse, o envolvimento de setores governamentais e privados tornam-se fundamentais para que se busque a recuperação, sendo esta uma tarefa que exige muito mais que procedimentos rotineiros.

Altay e Green (2006) dividem o gerenciamento de desastres em quatro fases distintas, que compõem o ciclo do desastre:

- mitigação: fase onde se aplica medidas de prevenção do aparecimento de um desastre ou redução dos impactos causados por este;

- preparação: medidas de treinamento da comunidade, antes da ocorrência do evento;

- resposta: recursos e procedimentos de emergência são empregados nesta fase, onde o foco é salvar vidas e prevenir danos futuros;

- recuperação: ações de longo prazo que tem como objetivo a busca pelo restabelecimento da infraestrutura atingida.

Quanto à ocorrência de desastres naturais no mundo, o estudo Global Strategic Trends - Out to 2045 (Reino Unido, 2014) divulgou que eventos extremos, como inundações e secas, devem aumentar em frequência e intensidade, sobretudo nas regiões com os mais altos níveis de desigualdade e de pobreza. 


\section{4}

\section{Militares e a assistência humanitária}

O emprego de meios (pessoal, material, estruturas) militares em operações de alívio após desastres e em ações humanitárias em geral foi regulado em 1994, num esforço colaborativo entre diversos países e organismos internacionais, que culminou com a publicação em Oslo, na Noruega, do Guia que ficou conhecido como “Oslo Guidelines” (Aversa, 2011).

Burkle (2005) destaca a assistência humanitária prestada pelas forças armadas como essencial em situações em que a presença de agências humanitárias é inexistente ou insuficiente ou quando o ambiente de segurança é proibitivo, impedindo acesso.

Já Oloruntoba (2010) relembra que alguns ativos que são rapidamente e efetivamente implantados em resposta a necessidades apresentadas por desastres são muitas vezes detidos por militares, como por exemplo, combustíveis, equipamentos para transportes e comunicações, equipamentos de engenharia e de construção, medicamentos e estoque de provisões como alimento e água.

Segundo Philips (2011), para que as unidades militares possam ser bemsucedidas em operações humanitárias, essas precisam ter capacidade de autodireção, serem ágeis, autossuficientes e multiqualificadas. Sendo assim, elas estarão prontas para operar em questões de horas, levando os equipamentos que lhe permitam estabelecer uma posição avançada de comando central das operações e atividades subsequentes. Além disso, devem ser capazes de se adaptar e de responder ao que lhes foi exigido, mesmo distantes da sua cadeia de comando e sede, tomando decisões rápidas com base em sua avaliação do ambiente.

As forças armadas são capazes de desempenhar um papel eficiente em catástrofes prestando apoio logístico por meio das diversas funções logísticas que se fizerem necessárias nestas operações. As principais missões dos militares em operações de respostas a desastres são: estabelecer um ambiente seguro para organizações humanitárias trabalharem, fornecendo transporte e comunicações (Davidson et al.1996).

Normalmente, as forças armadas do país onde ocorre um grande desastre costumam ser um dos primeiros atores a iniciarem a ajuda à população que foi afetada por tal ocorrência, por meio do envio de equipes de emergência ao local. 
O auxílio militar é algo comum em diversas ações humanitárias e pode oferecer os mais diversos benefícios para essas ações, uma vez que as forças armadas costumam ter seu campo de atuação mais voltado para capacidades operacionais, fundamentais na realização de atividades com este caráter (Weeks, 2007).

A Tabela 2, apresenta as atividades operacionais que podem ser realizadas por militares na assistência humanitária e apresenta uma breve descrição, dessas:

Tabela 2: Atividades realizadas por militares em ações humanitárias (Leaning et al., 1999).

\begin{tabular}{|c|c|}
\hline Atividade & Descrição \\
\hline Segurança & $\begin{array}{l}\text { Proteção dos locais de armazenagem, estabelecimento de pontos de } \\
\text { segurança, manutenção de uma presença armada com credibilidade a fim de } \\
\text { reduzir a violência e roubos. }\end{array}$ \\
\hline $\begin{array}{l}\text { Transporte e } \\
\text { Logística }\end{array}$ & $\begin{array}{l}\text { Habilidade de transportar recursos e pessoas de forma eficiente, além de } \\
\text { providenciar materiais e equipamentos durante todo o processo. }\end{array}$ \\
\hline $\begin{array}{l}\text { Construção e } \\
\text { Reparo }\end{array}$ & $\begin{array}{l}\text { Capacidade de construir ou reparar elementos essenciais para as atividades, } \\
\text { como estradas, pistas de pouso e pontos de apoio. }\end{array}$ \\
\hline $\begin{array}{l}\text { Controle e } \\
\text { Comunicaçãc }\end{array}$ & $\begin{array}{l}\text { Uso de sofisticados sistemas de comunicação. Forte capacidade de } \\
\text { organização, facilitando o controle das atividades. Capacidade de organizar } \\
\text { e responder rapidamente a contingências que possam vir a ocorrer. }\end{array}$ \\
\hline $\begin{array}{l}\text { Cuidados } \\
\text { Médicos }\end{array}$ & $\begin{array}{l}\text { Profissionais preparados e equipes de saúde qualificadas, planos de } \\
\text { evacuação e controle de doenças. }\end{array}$ \\
\hline $\begin{array}{l}\text { Forças } \\
\text { Especiais }\end{array}$ & $\begin{array}{l}\text { Profissionais treinados para ter o primeiro contato e atuar entre os militares } \\
\text { e a população em geral; engloba especialistas em transporte, leis, negócios, } \\
\text { comunicação, saúde, entre outros elementos fundamentais. }\end{array}$ \\
\hline Preparação & $\begin{array}{l}\text { Capacidade de agir, treinar e controlar de forma eficiente, respondendo } \\
\text { rapidamente a estados de calamidade. }\end{array}$ \\
\hline
\end{tabular}

\section{5}

\section{Características da cadeia humanitária}

Segundo Melo e Alcântara (2011), gestão da demanda é o processo que procura balancear os requerimentos dos clientes com a capacidade de atendimento da cadeia de suprimentos. Neste sentido, o processo produtivo deve ser 
desencadeado a partir de necessidades da demanda e essas necessidades é que devem mobilizar toda a cadeia de suprimentos.

Para as situações que envolvem demanda com caráter humanitário, Long e Wood (1995) entendem que o fato de cada desastre possuir características únicas pode ser considerado como a principal causa da dificuldade em se planejar para os estágios iniciais em casos de respostas humanitárias.

Já para Organização Pan-Americana de Saúde (OPAS, 2010), esta demanda pode ser prevista a partir de dois fatores importantes que a determinam, que são o tipo do desastre e a quantidade por tipo de suprimentos de ajuda necessários.

Segundo Howden (2009), a cadeia de fornecimento humanitária, demonstrada na Figura 2, inclui um escopo amplo de atuação de seus agentes devido à gama de atividades envolvidas nestas, como o relacionamento entre doadores, distribuidores, compradores, armazenadores, transportadores, compradores e beneficiários.

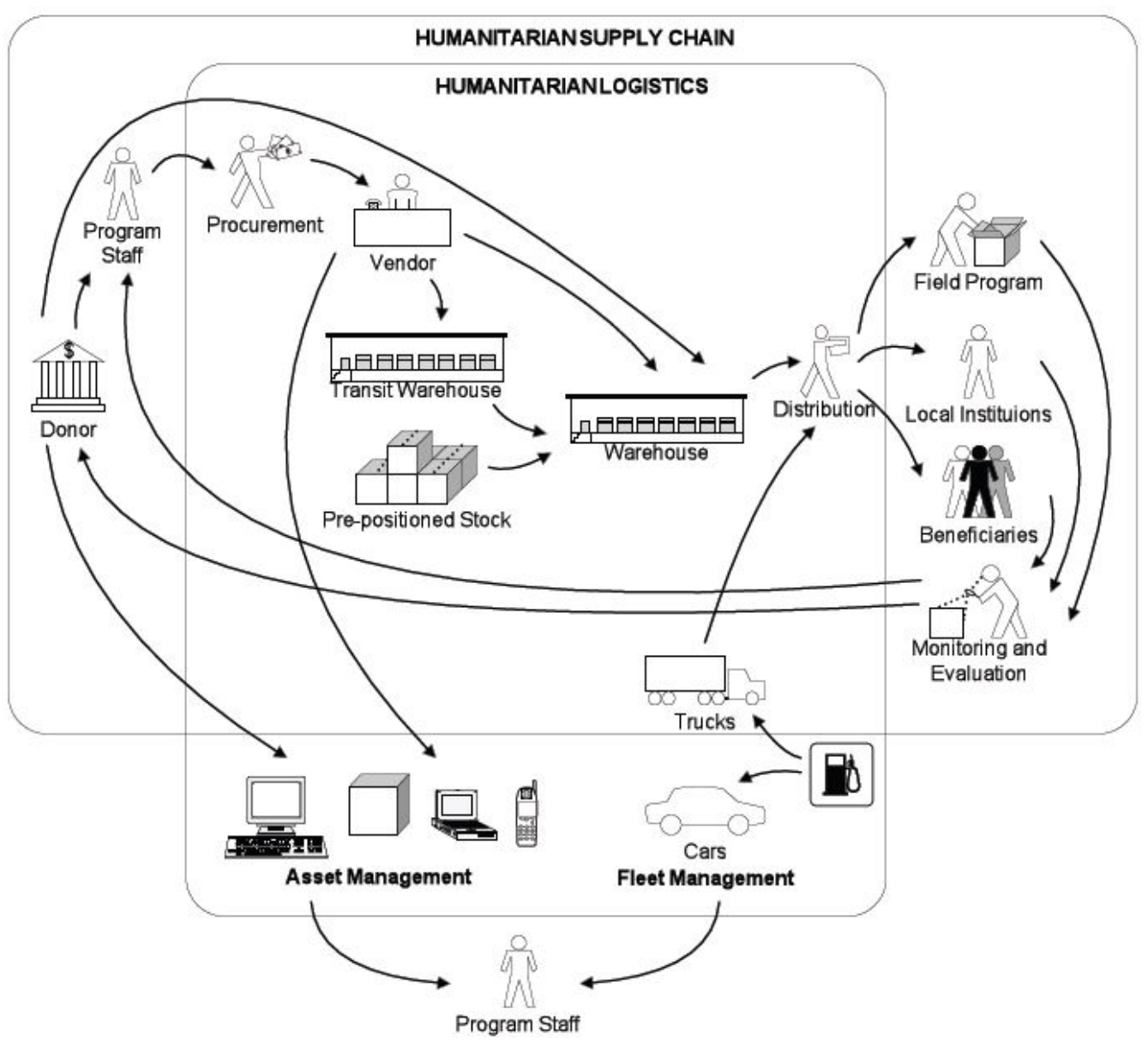

Figura 2: Cadeia humanitária de suprimentos (Howden, 2009). 
Para Balcik et al. (2010), os fatores principais que impactam a gestão de uma cadeia humanitária são:

- grande diversidade e número de atores envolvidos: cada entidade ou organização que atua em resposta a um desastre tem sua metodologia própria e modo de atuar;

- expectativas dos doadores e estrutura de financiamento: a maioria das entidades de ajuda humanitária depende diretamente de doações para que possam iniciar a reposta a um desastre. Desta forma, existe uma cobrança intrínseca por resultados e também de que forma as doações arrecadadas foram investidas;

- competição por doadores e os efeitos dos meios de comunicação: os meios de comunicação muitas vezes são considerados como fator crítico que afeta diretamente as operações de ajuda;

- imprevisibilidade: localização, duração e intensidade são geralmente fatores desconhecidos em desastres súbitos. Após a ocorrência de um desastre, fatores como a real situação da população e da infraestrutura da região atingida são imprevisíveis;

- escassez e/ou excesso de recursos: devido às incertezas associadas aos desastres (localização, duração, intensidade) e falta de recursos (financeiros, humanos, tecnológicos, informação), o que pode criar dificuldades de coordenação em toda a cadeia; e

- custos de coordenação: os custos são distribuídos em três níveis: estratégico, tático e operacional. 


\section{Logística da Marinha do Brasil}

Este capítulo analisa como se desenvolve a aplicação da Logística da Marinha do Brasil e como esta se comporta independente da missão em que atua, incluindo operações de caráter humanitário. Também aborda o tratamento da Logística no setor de Abastecimento da Marinha, descrevendo a Sistemática PROA (Prioridade Operativa do Abastecimento), sistemática essa, atualmente adotada pela Força para realizar o processo de abastecimento de seus meios visando a melhor utilização dos recursos disponíveis.

\section{1}

\section{Logística Militar no Brasil}

Nos dias de hoje, a logística tem obtido cada vez mais relevância no cenário das instituições que demandam disponibilidade de recursos e rapidez para realizarem suas atividades de forma plena, eficaz e eficiente.

Dentro do contexto da estratégia militar, pode-se observar que a logística exerce papel fundamental ao prover os recursos para apoio às forças combatentes necessárias à defesa da Pátria. O Ministério da Defesa, do Brasil, conceitua Logística Militar como "o conjunto de atividades relativas à previsão e à provisão dos recursos e dos serviços necessários à execução das missões das Forças Armadas" (Brasil, 2003).

Ainda que as Forças Armadas não sofram com a concorrência imposta por um mercado específico na busca de lucros, é amplo o entendimento entre seus membros de que a logística não pode ser negligenciada em suas organizações na busca por resultados mais eficientes aplicados em suas atuações, e sendo assim, deve ser entendida como atividade fundamental para o cumprimento de sua missão constitucional (Brasil, 2003) constante no artigo 142, da Constituição Federal (Brasil, 1988): 
“As Forças Armadas, constituídas pela Marinha, pelo Exército e pela Aeronáutica, são instituições permanentes e regulares, organizadas com base na hierarquia e na disciplina, sob a autoridade suprema do Presidente da República, e destinam-se à defesa da Pátria, à garantia dos poderes constitucionais e, por iniciativa de qualquer destes, da lei e da ordem."

Para a Doutrina de Logística Militar (Brasil, 2016a), que é a norma que regulamenta a atividade logística pelas Forças Armadas brasileiras, atividade logística é um conjunto de tarefas afins, reunidas segundo critérios de relacionamento, interdependência ou similaridade. Ou seja, a logística nas Forças Armadas brasileiras proporciona os meios humanos, materiais e serviços necessários para satisfazer suas necessidades e permitir que essas realizem suas atividades em tempos de guerra ou paz.

No Brasil, observa-se uma vasta capilaridade das Forças Armadas, reconhecida pela distribuição de várias organizações militares em todo o território nacional, e a capacidade de flexibilidade apresentada pelas Forças Armadas são fatores que favorecem uma resposta adequada e o desenvolvimento desta atividade na situação de desastres.

As Forças Armadas brasileiras embora sejam prioritariamente preparadas e adestradas para a defesa do País. Estas podem ser prontamente adaptadas para atender aos requisitos necessários à consecução de assistência humanitária, devido à sua flexibilidade. A organização, estrutura e prontidão das Forças Armadas possibilitam ao comando uma rápida resposta, necessária nesse tipo de atuação (Brasil, 2008).

\subsection{1}

\section{Doutrina logística da Marinha}

Pautada na possibilidade de uma reestruturação a partir da obtenção de novos meios, de acordo com o que está previsto na Estratégia Nacional de Defesa (Brasil, 2013b), a Marinha do Brasil cada vez mais vem identificando a necessidade de atualizar seu pensamento logístico adequando suas práticas atuais à execução de modernas práticas de gestão adotadas por diversos outros setores. Tal adequação só é viável a partir da atualização permanente de processos em seus níveis estratégicos, táticos e operacionais. 
A Marinha do Brasil, em consonância com a Doutrina de Logística Militar (Brasil, 2016a) estabelecida pelo Ministério da Defesa, adota para a realização de suas atividades, a seguinte definição para logística, conforme está descrito em seu Manual de Logística (Brasil, 2003):

"Logística é a componente da arte da guerra que tem como propósito obter e distribuir às Forças Armadas os recursos de pessoal, material e serviços em quantidade, qualidade, momento e lugar por elas determinados, satisfazendo as necessidades na preparação e na execução de suas operações exigidas pela guerra”.

Quando se trata especificamente da logística naval, o mesmo Manual de Logística (Brasil, 2003), define esta como:

“O ramo da logística militar concernente aos meios, efetivos e organizações de comando, controle, comunicações e apoio empregados pela Marinha para atender às necessidades das forças navais.”

Dentro da Marinha do Brasil, a logística é orientada pela Doutrina Básica da Marinha - DBM (Brasil, 2014), sob a regulamentação do Manual de Logística da Marinha (Brasil, 2003). A Doutrina Básica da Marinha (Brasil, 2014), como o próprio nome já deixa que se perceba, é o documento que formalmente serve de referência e base para todos os demais documentos doutrinários que norteiam a atuação da Marinha dentro dos mais diversos ramos em que esta atua. É por meio desta Doutrina, que a Marinha do Brasil trabalha, estabelecendo seus princípios, conceitos e métodos de emprego, tanto para ações de combate, como para participações não relacionadas à atividade-fim. O propósito deste documento é orientar a organização, o preparo e o emprego do Poder Naval brasileiro.

Para a Doutrina Básica da Marinha (Brasil, 2014), operações humanitárias são realizadas em outros países para reduzir os efeitos de desastres naturais ou acidentes provocados pelo homem, que representem séria ameaça à vida ou resultem em extenso dano ou perda de propriedade. A efetividade e eficácia que a Força busca nas ações de ajuda humanitária em que esta atua, depende da conjugação de todas as funções logísticas que estão regulamentadas na Doutrina de Logística Militar (Brasil, 2016a) e descritas no Manual de Logística da Marinha (Brasil, 2003), a saber suas definições:

- Suprimento: conjunto de atividades que trata da previsão e provisão do material, de todas as classes, necessário às organizações da Marinha e forças 
apoiadas. Esta função logística, juntamente com a função logística transporte, integra-se ao conceito mais abrangente de abastecimento, cujo o propósito é promover o fluxo adequado do material necessário, desde as fontes de obtenção até as organizações militares consumidoras.

- Manutenção: conjunto de atividades que são executadas visando a manter o material (meios e sistemas) utilizados pela MB na melhor condição para emprego e, quando houver defeitos ou avarias, reconduzi-lo àquela condição.

- Salvamento: conjunto de atividades que são executadas visando à salvaguarda e ao resgate de recursos materiais, suas cargas ou itens específicos. São atividades desta função logística: combate a incêndio, controle de avarias, controle de danos, remoção, reboque, desencalhe ou reflutuação de meios, e resgate de recursos materiais acidentados, cargas ou itens específicos.

- Saúde: conjunto de atividades relacionadas com a conservação do pessoal, nas condições adequadas de aptidão física e psíquica, por intermédio de medidas sanitárias de prevenção e recuperação. São atividades desta função logística: determinação dos padrões psicofísicos dos militares, seleção médica, medicina preventiva e medicina curativa.

- Recursos Humanos: conjunto de atividades relacionadas com o gerenciamento do pessoal necessário ao emprego das forças navais, aeronavais e de fuzileiros navais e ao funcionamento das organizações militares da Marinha.

- Transporte: conjunto de atividades que são executadas visando ao deslocamento de recursos humanos e materiais por diversos meios, em tempo e para os locais predeterminados, a fim de atender às necessidades.

- Engenharia: conjunto de atividades que são executadas, visando o planejamento e à execução de obras e de serviços com o objetivo de obter e adequar a infraestrutura física e as instalações existentes às necessidades das forças e demais organizações da Marinha do Brasil.

Para que ocorra a implantação de cada função logística descrita no Manual de Logística da Marinha (Brasil, 2003), um grande número de atividades relacionadas ao abastecimento, aquisição, transporte e seleção precisam ser identificadas e coordenadas. Dependendo do vulto e da importância da ação em que a função logística será aplicada, o estabelecimento de uma estrutura específica dentro da Marinha pode ser exigido para que este atendimento seja possível e viabilizado. São os casos das funções logísticas Suprimento, Recursos Humanos e 
Saúde, que possuem sistemas de apoio estruturados próprios que são, o Sistema de Abastecimento, o Sistema de Pessoal e o Sistema de Saúde, respectivamente.

\section{2}

\section{Documentos condicionantes da logística na Marinha do Brasil}

A regulamentação legal da logística na Marinha do Brasil, está condicionada em diversas bases legais que orientam como a Força deve proceder para que se mantenha alinhada com o que determina o Governo Federal no que se refere à logística para as organizações que estão subordinadas a esse. Dentro da esfera nacional, na Constituição Federal de 1988 (Brasil, 1988), que é a base de toda a legislação e doutrina que regem a atuação da Marinha do Brasil, estava prevista a criação de uma lei que detalharia o papel das Forças Armadas no Brasil, lançada em 1999 - a Lei Complementar 97 (Brasil, 1999).

Como já citado neste trabalho, para que as Forças Armadas possam cumprir sua missão constitucional de defesa da Pátria e garantia dos poderes constitucionais, é fundamental que seus alicerces estejam pautados em aplicações logísticas eficientes. O Livro Branco de Defesa (Brasil, 2012), no âmbito do Ministério da Defesa (MD), expressa que a Defesa Nacional, caracterizada na Política Nacional de Defesa (Brasil, 2013a), é o conjunto de medidas e ações do Estado, com ênfase na expressão militar, para a defesa do território, da soberania e dos interesses nacionais contra ameaças preponderantemente externas, potenciais ou manifestos, e que entre seus objetivos traz pelo menos dois tópicos voltados para a logística, que são:

- estruturar as Forças Armadas em torno de capacidades, dotando-as de pessoal e material compatíveis com os planejamentos estratégicos e operacionais; e

- desenvolver o potencial de logística de defesa e de mobilização nacional.

O Livro Branco de Defesa (Brasil, 2012) pretende ser um marco de transparência que direciona a atuação do Brasil como ator na construção de uma comunidade global participativa e inclusiva. Esse livro orienta que o Brasil deve consolidar mecanismos de governança voltados para a paz e a segurança mundiais e para o bem-estar da humanidade. 
A Política Nacional de Defesa (Brasil, 2013a) considera que para ampliar a projeção do Brasil no contexto mundial e reafirmar seu compromisso com a defesa da paz e com a cooperação entre os povos, o país deverá aperfeiçoar o preparo das Forças Armadas para desempenhar responsabilidades crescentes em ações humanitárias e em missões de paz sob a égide de organismos multilaterais, de acordo com os interesses nacionais.

Sendo assim, a Estratégia Nacional de Defesa (Brasil, 2013b) traçou metas para assegurar que os objetivos da Defesa Nacional pudessem ser atingidos. As diretrizes da Estratégia Nacional de Defesa (Brasil, 2013b) voltam-se para a preparação das Forças Armadas com capacidades adequadas para garantir a segurança do País, tanto em tempo de paz, quanto em situações de crise. O objetivo da Estratégia Nacional de Defesa (Brasil, 2013b) é atender às necessidades de equipamentos das Forças Armadas, privilegiando o domínio nacional de tecnologias avançadas e maior independência tecnológica.

Desta feita, a prontidão das Forças Armadas depende de um planejamento contínuo, cíclico e flexível que garanta seu pleno emprego estratégico e operacional e com solução de continuidade de seus planejamentos, principalmente no nível estratégico, mantendo-as modernizadas, equipadas, balanceadas, adestradas e motivadas para o desempenho de sua missão.

Ainda dentro das condições da logística a ser desempenhada pelas Forças Armadas do Brasil, dentre elas, a Marinha, a Doutrina de Logística Militar (Brasil, 2016a) serve de base doutrinária para o planejamento e a execução das atividades logísticas das Forças Armadas, no cumprimento das suas missões, e para o desenvolvimento de estudos voltados para a aplicabilidade, conceituação e normatização da logística militar.

A Doutrina Básica da Marinha (Brasil, 2014) estabelece os princípios, conceitos e métodos de emprego tanto para ações de combate como para participações não relacionadas à atividade-fim. O propósito desse documento é o de orientar a organização, o preparo e o emprego do Poder Naval brasileiro. Este documento é composto por cinco capítulos onde são apresentados os conceitos de Poder Nacional, Poder Marítimo e Poder Naval, de forma a situar este último em relação aos demais, enumerando as suas capacidades, características e tarefas básicas. A Doutrina Básica da Marinha (Brasil, 2014) aborda também os conflitos e o espectro de sua evolução, caracterizando a distinção entre guerra e conflito 
armado e sua relação com o emprego das Forças Armadas, descrevendo o conceito de guerra naval e as diversas formas de sua condução. Esta mesma Doutrina Básica (Brasil, 2014) trata o Poder Naval nas atividades de emprego limitado da força, por imposição da lei, caracterizando as situações em que são efetuadas, e apresenta como o Poder Naval é empregado nas atividades benignas que, por suas características particulares, não prevê o emprego da força.

A Doutrina de Logística da Marinha está descrita em seu Manual de Logística (Brasil, 2003), que se encontra adequada como que determina a Doutrina de Logística Militar (Brasil, 2016a) e também a Doutrina Básica da Marinha (Brasil, 2014) e tem como propósito apresentar todos os conceitos doutrinários básicos da Logística Militar e balizar como deve ser a execução dessa, na Força.

\section{3}

\section{Definição de ciclo logístico na Marinha}

Na Marinha do Brasil, o ciclo logístico também é conhecido como o processo de atendimento às demandas e, de acordo com seu Manual de Logística (Brasil, 2003) segue três etapas:

- Determinação de necessidades: constitui-se na fase básica mais importante do ciclo logístico por servir de fundamento às demais fases e, consequentemente, influir decisivamente na resolução do problema logístico. Para a realização desta fase, as seguintes perguntas são levantadas: o que é necessário? / quanto é necessário? / quando será necessário?/ onde será necessário?/ o que é mais importante?

- Obtenção: é a segunda fase básica do ciclo logístico. A disponibilidade dos recursos limita a obtenção, portanto, quando se evidencia a impossibilidade de obtenção de um determinado recurso, torna-se necessária a revisão da fase de determinação de necessidades.

- Distribuição: definida como a ação de fazer chegar, oportuna e eficazmente, aos utilizadores, os recursos logísticos fixados pela determinação de necessidades e viabilizados na fase de obtenção. Esta fase completa o ciclo logístico e possibilita a produção do resultado desejado. 
Este ciclo, conforme demonstrado na Figura 3, tem seu início quando os utilizadores passam a aplicar as fases que compõem tal ciclo e iniciam determinando suas necessidades e informando essas aos elementos que compõem todo o sistema logístico da Força.
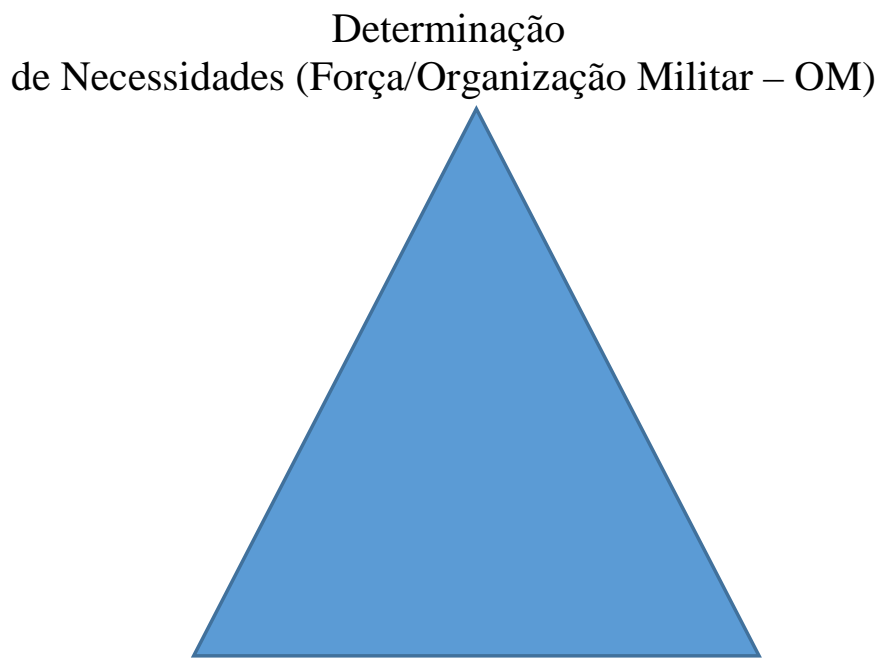

Obtenção (Órgãos de Apoio)

Distribuição (Usuário)

Figura 3: Ciclo Logístico na Marinha - Manual de Logística da Marinha (Brasil, 2003).

Para que as fases do ciclo logístico possam ser realizadas de maneira eficiente, é necessário que alguns princípios básicos sejam observados no planejamento e na execução das atividades logísticas. Esses princípios são (Brasil, 2003):

- Objetivo: é o efeito final desejado e é definido normalmente na missão. Ele é fundamental já que sem um objetivo claramente definido haverá o risco de os demais princípios tornarem-se sem sentido, podendo obscurecer a finalidade para dar ênfase ao emprego dos meios.

- Continuidade: é o encadeamento ininterrupto de ações, assegurando uma sequência lógica para as fases do trabalho.

- Controle: é o acompanhamento da execução das atividades decorrentes do planejamento, no sentido de permitir correções e realimentações, a fim de atingir o propósito estabelecido, com o sucesso desejado.

- Coordenação: é a conjugação de esforços, de modo harmônico, de elementos distintos e mesmo heterogêneos, com missões diversas, para a consumação de um mesmo fim. 
- Economia de Meios: é a busca do máximo rendimento, por intermédio do emprego eficiente, racional e judicioso dos meios disponíveis. Não implica na economia excessiva, mas na distribuição adequada dos meios disponíveis, elegendo-se como prioritário o apoio na área da ação principal.

- Flexibilidade: é a possibilidade de adoção de soluções alternativas ante a mudança de circunstâncias.

- Interdependência: é a dependência recíproca que o planejamento logístico mantém com o planejamento operacional nos níveis estratégico e tático.

- Objetividade: é a identificação clara das ações que devem ser realizadas e a determinação precisa dos meios necessários à sua concretização.

- Oportunidade: é o condicionamento da previsão e da provisão dos meios ao fator tempo, a fim de que as necessidades possam ser atendidas de forma adequada.

- Prioridade: é a prevalência do principal sobre o secundário ou acessório.

- Segurança: é a garantia do pleno desenvolvimento dos planos elaborados, a despeito de quaisquer óbices. Consiste nas medidas necessárias para evitar a surpresa, a observação, a sabotagem, a espionagem e a inquietação, a fim de assegurar a liberdade de ação do Comandante. Não implica em precaução exagerada nem em evitar o risco calculado.

- Simplicidade: é o uso da linha de ação mais simples e adequada ao desenvolvimento das atividades logísticas, de modo a ser compreendida e executada com facilidade.

- Unidade de Comando: é a existência de autoridade e programa únicos para um conjunto de operações com a mesma finalidade. Uma unidade de comando eficiente requer uma cadeia de comando bem definida, com precisa e nítida divisão de responsabilidades, um sistema de comunicações adequado e uma doutrina logística bem compreendida, aceita e praticada pelos Comandantes em todos os níveis.

O trabalho de determinar necessidades é baseado em um plano estratégico ou operativo específico, que são as fontes de dados iniciais com que o problema se depara. Estes dados iniciais são imprescindíveis para a realização desta fase básica, já que será por meio destes que serão indicados quem necessita do quê, para qual missão será necessário, qual o local da missão e o que está disponível. 
A fase de determinação de necessidades é realizada pelos usuários dos sistemas da Marinha e iniciam todo o ciclo. Estes usuários podem ser OM (meios navais, aeronavais e de fuzileiros navais), ou a Força como um todo, propriamente dita. A realização desta fase básica ao ciclo logístico ocorre quando as seguintes perguntas são respondidas pelos agentes que realizam tarefas afetas a logística aplicada na Marinha:

- O que é necessário? A resposta a esta pergunta deve envolver a especificação da qualidade do que se necessita.

- Quanto é necessário? Devido à escassez de recursos disponibilizados, a quantidade do que será necessário para uma missão, dentro das características desta, demonstra a relevância de tal resposta.

- Quando será necessário? Aqui o que se aborda é a definição do tempo em que a necessidade precisará ser atendida.

- Onde será necessário? A resposta a esta pergunta será em que local a necessidade deverá ser atendida.

- O que é mais importante? Aqui temos o ponto em que prioridades as necessidades devem ser atribuídas.

Na Marinha, a fase de obtenção normalmente é realizada pelo Centro de Obtenção da Marinha no Rio de Janeiro, organização militar localizada na cidade do Rio de Janeiro, que tem como propósito, em linhas gerais, promover ou proceder a procura e a aquisição, de forma centralizada, do material pertencente à linha de fornecimento do Sistema de Abastecimento da Marinha. Porém, não existe uma obrigatoriedade institucional nem normativa de que todas as obtenções necessárias a realizações de missões devam ser realizadas por este Centro de Obtenção, o que descentraliza o trabalho e pode resultar em gargalos de esforços nesta fase do ciclo logístico. Ou seja, a fase de obtenção na Marinha trabalha de forma descentralizada, podendo até mesmo ser realizada por Organizações Militares que estejam fora do Sistema de Abastecimento. Esta descentralização dificulta o gerenciamento de demanda dentro da Marinha, pois, em momentos críticos, se o local de armazenamento do material necessário a operação for desconhecida do solicitante, pode ser considerada uma desvantagem, pois o 
gerenciamento de níveis de estoque pode levar a um desperdício de tempo, considerado fator relevante em ações humanitárias.

Encerrando a aplicação do ciclo logístico, chega-se à fase de distribuição, que é uma fase eminentemente executiva e ocorre entre dois elementos, um órgão de apoio, que não necessariamente é um órgão de obtenção e um órgão receptor, que é a organização militar consumidora ou utilizadora e não propriamente a que determinou a necessidade.

De forma resumida, a aplicação deste ciclo se dá tão logo a informação é recebida, e o dado é consolidado e comparado com o que está disponível e conhecido na Força. Caso sejam identificadas deficiências de atendimento aos usuários para a realização de alguma missão, serão tomadas providências pelos elementos que atuam no ciclo logístico para que a partir de critérios preestabelecidos possa ser realizada a obtenção e posterior distribuição aos usuários, fechando o ciclo.

\section{4}

\section{Tratamento da atividade do abastecimento dentro da logística da Marinha}

Para que a Marinha pudesse se alinhar com a Doutrina de Logística Militar (Brasil, 2016a), que adota recursos humanos, saúde, suprimento, manutenção, engenharia, transporte e salvamento como funções logísticas, a Força não trata Abastecimento como uma função logística específica, integrando este a um conceito mais abrangente, que engloba a função logística suprimento, parte da função logística transporte, além de relacionar-se estritamente com a função logística manutenção, cujo o propósito é promover o fluxo adequado do material necessário, desde as fontes de obtenção até as organizações militares consumidoras. Desta maneira, entende-se que a atividade abastecimento está inserida na proposta de ciclo logístico da Força e, assim, em sua logística.

O problema a ser solucionado pelo setor do abastecimento na Marinha consiste em buscar respostas para as seguintes perguntas:

- “QUE” material é necessário?: aqui o importante para aquele que determinará a necessidade é informar a qualidade do que se precisa e o tipo com a 
melhor especificação possível, para que não se desperdice esforços com o material que não satisfazer a necessidade.

- “QUANTO” é necessário?: mais uma vez a questão da quantidade a ser obtida se faz presente, pois a subestimação ou superestimação do que se faz necessário poderá comprometer o todo de uma missão a ser realizada.

- “QUANDO”?: o tempo que deve ser provido o que se faz necessário. Deve ser sempre levado em consideração por aqueles que realizam a atividade do Abastecimento.

- “ONDE”?: considera-se que uma necessidade estará plenamente atendida se esta estiver disponível no local em que se fizer necessário.

Sendo assim, tamanho é o espectro de variáveis que devem ser consideradas pelo setor do Abastecimento que as respostas a estas perguntas não podem ser classificadas em apenas uma função logística quando se trata especificamente de ajuda humanitária, e sim pelo relacionamento entre pelo menos as três funções logísticas citadas acima, adotadas pela Força. É desta forma que o setor do Abastecimento se insere no ciclo logístico da Marinha.

Estar em condições de realizar suas atividades e tarefas constitucionais, tão logo se faça necessário, é o propósito maior que uma instituição como a Marinha do Brasil deve sempre buscar, porém, para isso se faz necessário que esta tenha um sistema de apoio logístico que esteja alinhado e principalmente operando de forma adequada sempre que se fizer necessário, suportado por sistemas de informação que permitam o gerenciamento da cadeia de suprimentos.

Sendo assim, a gestão de produtos e informações, que transitam pelos órgãos da Marinha do Brasil que atuam em cada uma das funções logísticas adotada pela Força na realização de alguma missão, deve ser realizada por meio de estratégias que utilize sistemas de informação capazes de permitir eficiência, melhorando a integração dos processos, além de facilitar o gerenciamento das atividades operativas realizadas e aquelas relacionadas ao abastecimento, visando aumentar o controle e obter informações precisas que possam agilizar a tomada de decisão, melhorando o nível do atendimento a ser prestado pelos militares que estão atuando na missão que lhe foi designada.

É com este foco que aqueles que trabalham envolvidos com os processos de abastecimento da Força devem estar voltados sempre para a busca de um melhor aproveitamento dos recursos disponíveis, permitindo que a atividade do 
abastecimento e seu sistema, esteja permanentemente preparado para atuar nas diversas situações em que for requisitada a Marinha.

Para que os processos que envolvam atividades de abastecimento se desenvolvam dentro de um planejamento logístico que permita o estabelecimento de estratégias de gestão, de previsão de demanda e de níveis de estoques adequados a serem seguidas dentro da Marinha, faz-se relevante o estabelecimento de uma Diretiva de Abastecimento que viabilize este planejamento, indispensável em ações que envolvam caráter humanitário, e foi desta maneira que se estabeleceu pela Diretoria de Abastecimento da Marinha, a Diretiva de Planejamento do Abastecimento da Marinha (DIPLAB).

Estão inseridas na Diretiva de Planejamento de Abastecimento da Marinha várias ações e sistemáticas a serem adotadas pelas Organizações Militares que compõem o sistema de Abastecimento, mais especificamente aquelas subordinadas à Diretoria de Abastecimento.

Inserida na DIPLAB, e aplicada a possibilitar apoio de abastecimento adequado aos meios operativos, desenvolveu-se uma sistemática denominada como: Prioridade Operativa do Abastecimento (PROA), que visa viabilizar a efetividade do abastecimento dos suprimentos que se fizerem necessários para o cumprimento de qualquer missão da Marinha do Brasil, com prioridade para as que envolverem apoio humanitário seja em território nacional ou aqueles requeridos no exterior.

A implantação do conceito de Prioridade Operativa do Abastecimento, no Sistema de Abastecimento da Marinha, visa possibilitar o apoio adequado aos meios operativos, que realizarão comissões com prazo de afastamento de portos brasileiros superior a 30 dias.

A iniciativa da sistemática PROA surgiu a partir das experiências adquiridas pelo Sistema de Abastecimento nos diversos apoios prestados por este sistema aos meios operativos da Marinha do Brasil. A proposta é que o apoio ocorra dentro da sistemática englobando todas as categorias de material existentes na linha de suprimentos do referido sistema.

Sendo assim, para que esta sistemática seja de possível aplicação, as seguintes ações devem ser empreendidas:

- após a informação anual de quais meios realizarão missões no exterior, os meios localizados no Rio de Janeiro, deverão informar ao Centro de Controle de 
Inventário da Marinha para que esta OM possa enquadrá-los dentro de uma prioridade. Para os meios sediados fora do Rio de Janeiro, a informação quanto a missão no exterior deverá ser dada aos Centros de Intendência da área a que estão sediados.

- o meio que tiver previsão de realizar alguma missão no exterior deverá cumprir procedimentos específicos de prazos para que ocorra a possibilidade de atendimento oportuno das necessidades. A ausência de cumprimento de prazos promove grande degradação de atendimento fruto dos tempos de procura e aquisição, além de trâmites administrativos que mesmo com atribuição de caráter de urgência, enfrentam restrições de ordem legal.

- a realização de troca de informações entre os envolvidos deve ser incentivada para que críticas sejam feitas, além de sugestões para aperfeiçoamento, alertas quanto à premência de solicitações de material considerados imprescindíveis para a prontidão dos meios operativos, além de informações sobre soluções alternativas encontradas e avaliação do desempenho da rede de órgãos especializados do Sistema de Abastecimento da Marinha, assim como quaisquer observações que contribuam para a efetividade do abastecimento na Marinha.

Vale ressaltar que qualquer meio que seja solicitado a participar de operações de caráter humanitário, terão prioridade máxima em relação a qualquer outro, dentro da Marinha.

Como instrumento para uma melhor gestão da demanda, a sistemática PROA pode ser encarada como importante componente para o sucesso do gerenciamento da cadeia de suprimentos da Marinha. A manutenção e a busca por melhorias podem gerar benefícios substanciais para os processos de abastecimento, principalmente no que se refere à gestão de níveis de estoques.

Convencionalmente, no que se refere à gestão da demanda, opta-se por antecipar esta por meio de previsões de consumo, porém em ações que envolvam socorro a casos de desastres não há subsídios suficientes para esta antecipação e a possibilidade de flexibilidade que esta sistemática propõe pode ser um importante instrumento que permita a Marinha reagir com maior rapidez, proporcionando maior agilidade de atuação em ações humanitárias. 
A sistemática PROA deve ser encarada como um conjunto de procedimentos que visa o aprimoramento no planejamento logístico dos escassos recursos disponíveis para a Marinha do Brasil.

\section{5}

\section{Execução da logística humanitária na Marinha e suas funções}

Iniciada uma operação de qualquer natureza pela Marinha do Brasil, gradualmente iniciam-se ações logísticas para que se apoie tal operação em seu cumprimento, o que se não for bem planejado, pode causar sobrecarga na cadeia logística de apoio da Força. Em situações de crise, o esforço logístico que a Marinha do Brasil realiza para executar suas atividades operativas e administrativas rotineiras torna-se insuficiente para atender todas as necessidades que se apresentam, podendo a sistemática PROA ser encarada como uma importante ferramenta que permita a execução da logística de forma que as funções logísticas a serem realizadas não desperdicem recursos escassos.

A Marinha do Brasil, a partir de sua organização logística, entende que o apoio logístico é um ponto sensível em qualquer operação que envolva militares e meios a serem empregados. A sensibilidade do apoio prestado em ações humanitárias exige especificidades, como uma resposta rápida e intensificação de diversos esforços, que se forem bem coordenados possibilitam prover as populações em situações de crise, a ajuda que precisam. Uma logística rápida, planejada, ágil e flexível é, portanto, capaz de reduzir o impacto dos desastres e salvar vidas.

Sendo assim, por meio de seu Manual de Logística (Brasil, 2003) a Marinha do Brasil entende que quando o poder nacional se torna incapaz de prover os recursos necessários para o funcionamento rotineiro de um país por meio de sua logística, este pode e deve buscá-los em outros países. Este entendimento deixa claro que para a Força, nações que tenham condições de ajudar podem contribuir com recursos que estejam disponíveis e se fizerem necessários em outros países atingidos por eventos como os aqui tratados, os terremotos no Haiti e Chile.

Por ocasião do emprego da Marinha em ajuda humanitária, algumas funções logísticas se sobressaem. É o caso das funções: saúde, transporte, engenharia e 
suprimento. A função logística saúde deve realizar as seguintes atividades, de acordo com o Manual de Logística da Marinha (Brasil, 2003):

- levantamento de necessidades;

-determinação dos padrões psicofísicos dos militares;

- seleção médica;

- medicina preventiva; e

- medicina curativa.

Dentro do escopo de ajuda humanitária, fica evidente que não serão todas essas atividades que serão realizadas pela função logística saúde, priorizando-se as atividades de levantamento de necessidades para atender o evento, que é o processo que determina as necessidades de instalações, de pessoal e de material para o apoio de saúde em uma situação específica, e a medicina curativa, que é a atividade destinada ao tratamento de doentes e feridos, sob o regime ambulatorial ou hospitalar e que tem por finalidade devolver ao elemento humano as condições psicofísicas que o capacite a retornar, o mais breve possível, as suas atividades normais. As seguintes tarefas enquadram-se na medicina curativa: primeiros socorros, triagem, evacuação médica, hospitalização, tratamento ambulatorial, apoio odontológico e apoio ambulatorial. Todas essas tarefas são possíveis de serem realizadas por profissionais que atuam na Marinha.

Para que todas as outras funções logísticas possam realizar seus propósitos, de alguma forma, elas necessitam da função logística transporte. Esta função pode ser definida como o conjunto de atividades que são executadas dentro do ciclo logístico visando o deslocamento de recursos humanos e materiais por diversos meios, em tempo e para os locais predeterminados, a fim de atender às necessidades que surjam decorrentes do problema logístico. Trata-se primordialmente de um serviço e está presente principalmente na fase de distribuição do ciclo logístico, e dentro da Marinha do Brasil, abrange as modalidades rodoviária, aquaviária e aérea, por meio de suas respectivas vias. Por ter capacidade de operar meios de transporte, marítimos, aéreos e terrestres, esta função logística promove a capacidade de flexibilidade que a Marinha do Brasil tem para atuar em ações humanitárias, por meio do emprego dos diversos meios, aqui citados, já que o apoio que se fizer necessário poderá chegar no local atingido independente das condições de infraestrutura apresentada. Esta flexibilidade é um fator positivo diferencial na atuação da Marinha. 
Dentro das atividades realizadas pela função logística transporte na Marinha, estão:

- levantamento de necessidades: exame pormenorizado das ações e operações previstas pela Força, realiza o planejamento das necessidades para períodos subsequentes. Em caso de apoio a operações humanitárias, precisará ser revista.

- seleção: consiste no atendimento de prioridades, na escolha da modalidade de transporte a ser adotada e o meio de transporte a ser empregado, com base no conhecimento das possibilidades dos meios e das vias de transporte.

- gerência de transportes: consiste em aproveitar de maneira eficiente as disponibilidades existentes, obter o máximo rendimento dos meios disponíveis, com segurança e flexibilidade e estabelecimento de medidas de coordenação e de controle sobre o movimento de material ou de pessoal.

Ainda tratando das funções logísticas mais relevantes para a ajuda humanitária, a função engenharia desenvolve as seguintes atividades: construção, ampliação, reforma, adequação, reparação, restauração, conservação, demolição, remoção, desobstrução, montagem e avaliação. Fica evidente a relevância desta função já que em um ambiente onde a destruição e o caos se encontram instalados, atividades relacionadas como as realizadas pela função logística engenharia são mais do que necessárias, tendo a Força capacidade técnica para realizá-las.

Por último, a função logística suprimento trata da previsão e provisão de todo o material, de todas as classes, necessário às organizações, portanto, é impensável a realização de qualquer atividade pela Marinha do Brasil sem a realização bem-feita de tarefas desta função logística. As tarefas desta função logística envolvem os aspectos técnicos e gerenciais do ciclo logístico realizado na Marinha. É na função logística suprimento somada à função logística transporte que o conceito de Abastecimento se desenvolve. 


\section{Atuação da Marinha do Brasil em operações humanitárias - os casos dos terremotos no Haiti e no Chile em 2010}

Este capítulo apresenta o estudo de dois casos relativos a atuação da Marinha, as ações realizadas e seu envolvimento nas operações com caráter humanitário, durante os terremotos do Haiti e do Chile, ambos ocorridos no ano de 2010. Porém, antes de iniciar-se a realização do estudo de caso propriamente dito é importante ressaltar aspectos relacionados a doutrina logística aplicada por militares da Marinha do Brasil, para que por meio da implantação de sistemáticas como a PROA, tratada no capítulo 4, os complexos problemas de apoio apresentados a Marinha em casos semelhantes sejam resolvidos adequadamente.

Neste capítulo, o que se pretende é descrever como se deu cada um dos eventos, analisar cada um deles, compará-los e avaliar como se comportou a logística da Força, quando acionada para participar de operações que envolvam ajuda humanitária.

\section{1}

\section{A aplicação da doutrina logística pela Marinha do Brasil}

A participação de militares em operações de respostas a desastres, inicialmente pode parecer inapropriada, já que Forças Armadas destinam-se primordialmente à defesa da Pátria, à garantia dos poderes constitucionais e da lei e da ordem. Por isso, de acordo com da Rosa e Bandeira (2016), os princípios comuns às ações humanitárias, como a imparcialidade e neutralidade, não podem ser implementados pelos militares. Porém, a assistência humanitária prestada pelas Forças Armadas pode ser essencial nos casos em que organizações não governamentais não conseguem atuar. Ainda para os mesmos autores, o apoio militar inicial garante uma resposta rápida de socorro às vítimas, até que a ajuda humanitária possa chegar ao local do desastre, como os casos dos desastres ocorridos em Samoa (2009) e Haiti (2010). 
Diversos são os exemplos que garantem amparo legal da aplicação de militares atuando em apoio a situações de desastres. Nos Estados Unidos, de acordo com o Stafford Act (EUA, 2013), uma vez caracterizada as consequências imediatas de um evento que seja qualificado como desastre, o Governador do Estado onde o incidente ocorreu pode solicitar ao Presidente para que este permita a utilização do Departamento de Defesa Americano (DoD) com o propósito de atuar no público e no privado, em qualquer trabalho de emergência que seja necessário, onde o essencial seja a preservação da vida e da propriedade.

No Chile, foi estabelecido pelo Estado um Plano de Proteção Civil que busca melhorar o comportamento de toda a nação frente a um desastre e a participação das Forças Armadas Chilenas neste Sistema, de acordo com o Livro de Defesa do Chile (Chile, 2010), que embora sua função seja a defesa da pátria e a segurança nacional, estas podem contribuir com suas capacidades frente a desastres ou emergências.

No Brasil, de acordo com as Instruções para Emprego das Forças Armadas em apoio à Defesa Civil (Brasil, 2016b), a missão das Forças Armadas, como atribuição subsidiária geral, é:

\footnotetext{
"Cooperar, mediante autorização, com os órgãos e entidades que possuem competências relacionadas com a Defesa Civil. Para isso, ficar em condições de apoiar ações preventivas, incluindo planejamentos, instrução e simulações, e de resposta a desastres, tudo com vistas a evitar ou mitigar os efeitos daquelas ocorrências; a preservar o bem-estar da população; e a restabelecer a normalidade social.”
}

De acordo com a Diretriz Ministerial nº 004 (Brasil, 2001), que regulamenta quando e como deve se dar a atuação das Forças Armadas brasileiras nas atividades de Defesa Civil, esta deve ocorrer em regime de cooperação e, excetuando-se as tarefas específicas de coordenação atribuída a cada Força Armada, a coordenação das ações caberá ao órgão de Defesa Civil com jurisdição sobre o local do incidente. Somente em situações excepcionais, em decorrência da magnitude dos meios empregados para prestar o devido apoio, o Ministério da Integração Nacional poderá solicitar que o Ministério da Defesa assuma a coordenação.

Sendo assim, para Oliveira Netto (2014), as Forças Armadas brasileiras estão legalmente amparadas para oferecer suporte aos órgãos de Defesa Civil, tanto para iniciativas preventivas, de reconstrução, e de busca e salvamento das 
pessoas que estejam em situação de risco. Em relação a material e pessoal, a contribuição dos militares também é fundamental nos cenários de desastres (especialmente os decorrentes de eventos naturais), situação de emergência ou estado de calamidade pública, isto porque as Forças Armadas dispõem de pessoal treinado, e de equipamentos para enfrentar situações de crise.

A Doutrina de Logística Militar (Brasil, 2016a), serve de base para o planejamento e a execução das atividades logísticas das Forças Armadas, no cumprimento de suas missões, entre elas a missão subsidiária de prestar assistência humanitária, caso seja solicitado. Esta Doutrina prevê sob conceito de interoperabilidade, que é o aproveitamento de competências, capacitações e meios entre organizações para a solução de um problema logístico, que cada Força possuindo peculiaridades próprias, desenvolva procedimentos e ações específicas de ação para cada uma, sem, contudo, conflitar com os seus fundamentos doutrinários logísticos.

Para Varella et al, (2013), no contexto humanitário, uma operação militar precisa ser eficaz e bem coordenada do ponto de vista logístico, pois isso pode significar o salvamento de vidas e a diminuição do impacto total do desastre.

Foi sob esta base que a sistemática PROA foi idealizada e passou a ser implantada na Marinha a partir de 2011. Vale aqui ressaltar que esta sistemática era inexistente à época dos dois eventos aqui estudados, o que ressaltou aos olhos dos tomadores de decisão da Força que alguma coisa deveria ser idealizada para que toda a logística da Marinha pudesse ser realizada de forma eficiente e sem desperdícios em qualquer época, e mais ainda em momentos de crise, como aqueles em que o ambiente está afetado e vidas humanas estão em risco e o nível de tensão entre os que estão operando nessas ações está bastante elevado, o que amplia a complexidade do problema logístico.

Vale destacar que a aplicação da sistemática PROA para o abastecimento dos meios que atuam em alguma missão não isenta a Força de realizar suas aquisições sem o devido procedimento legal de licitação, previsto na Lei $n^{\circ}$ 8.666/93 (Brasil, 1993). Mesmo as aquisições a serem utilizadas em situações como as tratadas por esta pesquisa que requerem uma política rápida de aquisição muitas vezes sofrem limitações devido aos procedimentos legais que hoje estão disponíveis no Brasil dificultando a realização de tais missões. 
As leis brasileiras e normas da Marinha que estão em vigor requerem a abertura de procedimentos licitatórios para a compra de bens e serviços pelos órgãos públicos. Essa imposição, que caracteriza-se como uma restrição de ações, representa um retardo temporal, considerável nas obtenções que se fazem necessárias para a atuação nesse tipo de operação, pois mesmo que seja assinado um decreto estabelecendo a situação de calamidade pública, dependendo da localização do desastre, a Marinha não poderá se valer do mecanismo de dispensa de licitação, uma vez que seu principal órgão de obtenção fica localizado na cidade do Rio de Janeiro, fator que torna-se muito agravado quando tratamos de atuações em desastres internacionais.

\section{2}

\section{Terremoto no Haiti em 2010}

Muitos fatores ambientais, políticos e sociais fazem do Haiti um país extremamente vulnerável a desastres e com baixa resiliência, tendo ficando essa característica muito evidente no terremoto de 2010 e nas constantes tempestades, inundações e deslizamentos que ocorrem no país.

Entre às $19 \mathrm{~h} 30$ e 20h do dia 12 de janeiro de 2010, horário de Brasília, ocorreram doze tremores de terra com epicentro localizado a $10 \mathrm{Km}$ a SW de Porto Príncipe - Capital do Haiti, conforme mostrado na Figura 4. Estes tremores deixaram cerca de 300 mil mortos na nação considerada a mais pobre do continente, de acordo com Aguilar (2012). O terremoto que atingiu o Haiti foi classificado como de magnitude 7,3 na escala Richter e vários choques secundários atingiram a mesma região nos dias subsequentes, incluindo um outro terremoto de 5,9 graus no dia 20 de janeiro.

O terremoto do Haiti é um exemplo de desastre natural, que possui baixa frequência, porém foi geograficamente concentrado e com grande potencial de impacto. Este terremoto atingiu o centro econômico, administrativo, político e populacional do país, concentrando, de acordo com a Organização Panamericana de Saúde (OPAS, 2010), 66\% do Produto Interno Bruto (PIB) do país e 39\% da população que estava localizada na cidade de Porto Príncipe, capital do país e seus entornos. 


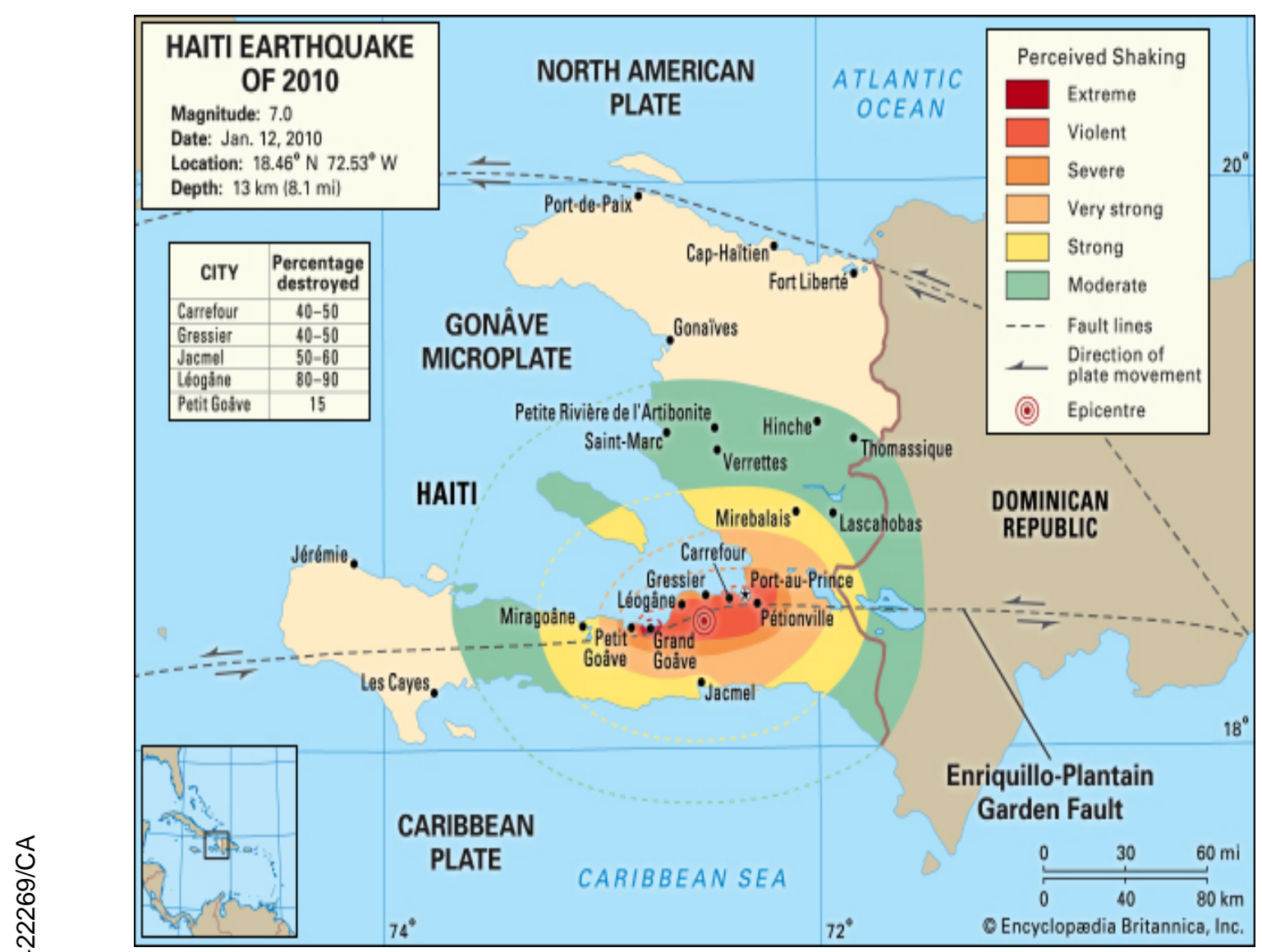

Figura 4: Intensidade do tremor nas áreas atingidas do Haiti, pelo terremoto de 2010 (Pallardy, 2016).

Mesmo antes do terremoto, a Organização Panamericana de Saúde (OPAS, 2009) já apresentava uma situação crítica para o Haiti onde, em relação ao acesso aos serviços básicos de saneamento e saúde, menos da metade da população possuía acesso e mesmo assim de baixa qualidade. Em relação aos serviços de saúde, $47 \%$ dos haitianos não possuía acesso a atenção básica e $75 \%$ da atenção à saúde era promovida por Organizações não Governamentais (ONGs) ou grupos religiosos, com maioria sem nenhum controle de órgãos governamentais. O Haiti apresentava-se com os mais baixos percentuais de população com acesso a água potável e esgotamento sanitário, o que resultava em um quadro precário de saúde, com altas taxas de doenças transmissíveis e parasitárias.

A situação socioeconômica do Haiti a época do território pode ser resumida segundo a Organização Panamericana de Saúde (PAHO, 2011), da seguinte maneira:

- um dos mais pobres e pequenos países do mundo e o menos desenvolvido na região da América; 
- alto nível de corrupção, iniquidade e desigualdade;

- grave deterioração ambiental;

- ausência de indústrias produtoras de material com potencial a ser exportado; e

- maioria dos serviços prestados por ONGs.

A Tabela 3 retrata resumidamente como o Haiti se encontrava logo depois do terremoto de 2010:

Tabela 3: Resumo de danos e perdas, no terremoto de 12 de janeiro de 2010 - Haiti (Haiti Grassroots Watch, 2011).

\begin{tabular}{|c|c|}
\hline Mortos & Aproximadamente $300 \mathrm{mil}$ \\
\hline Feridos & 300.572 \\
\hline $\begin{array}{l}\text { Casas colapsadas ou severamente } \\
\text { danificadas }\end{array}$ & 1.883 .830 \\
\hline Hospitais destruídos & 30 \\
\hline Escolas destruídas & 3.978 \\
\hline Infraestrutura destruída & $60 \%$ \\
\hline Perdas econômicas estimadas & $66 \%$ do PIB \\
\hline
\end{tabular}

A Marinha do Brasil possui uma Base de Fuzileiros Navais no Haiti para o desenvolvimento de ações relacionadas a MINUSTAH (Missão das Nações Unidas para a Estabilização do Haiti), que foi instalada no Haiti no ano de 2004. A MINUSTAH foi originalmente criada com o objetivo de apoiar o governo transitório instaurado no Haiti após uma série de convulsões políticas, e previa três pontos chaves, que eram: manutenção de um ambiente seguro e estável, contribuição no processo político pelo qual o país estava atravessando e preservação dos direitos humanos (Dias, 2011).

De acordo com o Relatório da Marinha sobre a ajuda humanitária ao Haiti (Brasil, 2010a), equipes de saúde do Grupamento Operativo de Fuzileiros Navais foram acionadas, participando do atendimento às vítimas dos desabamentos do Hotel Christopher, sede da MINUSTAH, e do Forte Nacional, construções localizadas na capital do país. Devido ao grande número de vítimas decorrentes do terremoto, o efetivo de médicos e enfermeiros que já atuavam neste Grupamento 
Operativo foi considerado insuficiente para atender as demandas que se apresentaram.

As Forças Armadas norte-americanas, detentoras de grande capacidade logística, assumiram, temporariamente, o protagonismo das ações de ajuda, viabilizando uma rápida resposta. De acordo com Keen et al. (2010), para que vidas sejam salvas na ocorrência de desastres naturais é fundamental que a reação seja rápida e eficaz. No caso do Haiti, esta necessidade foi ressaltada, devido à devastação do terremoto e à incapacidade de resposta do governo haitiano, frente ao problema.

No dia 13 de janeiro, de acordo com a Nota à Imprensa $n^{\circ} 03$ (Brasil, 2010b), foi realizada no Ministério da Defesa brasileiro, uma reunião de emergência para tratar sobre as ações que iriam ser tomadas frente ao evento ocorrido no Haiti. Decorrente desta reunião, o Estado Maior da Armada (EMA), que é o Órgão de Supervisão Geral dos sistemas que atuam nas funções logísticas de suprimentos, recursos humanos e saúde, informou aos setores do Comando de Fuzileiros Navais (CGCFN), Comando de Operações Navais (ComOpNav) e Diretoria Geral de Pessoal da Marinha (DGPM) sobre a solicitação de apoio a ser prestado pela Marinha do Brasil para a MINUSTAH, de água engarrafada, ração operacional e material de saúde, para aplicação a nível emergencial.

Em condições normais, os suprimentos que são destinados ao Haiti ficam armazenados temporariamente no $1^{\circ}$ Depósito de Suprimento, também chamado de Paiol Brasil, situado no Batalhão Logístico de Fuzileiros Navais, na cidade de Duque de Caxias, Rio de Janeiro (Aquino, 2008), aguardando a oportunidade de embarque em voo de transporte, normalmente com periodicidade quinzenal, ou embarque em navios da Marinha, com periodicidade semestral. Porém, as demandas iniciais decorrentes do pós-terremoto por não serem previstas, não tinham políticas de estoques estabelecidas, com pontos de reabastecimento e níveis de segurança perfeitamente definidos que permitissem garantir continuidade da cadeia logística.

No dia 15 de janeiro de 2010, o Estado Maior de Defesa solicitou que um hospital de Campanha da Marinha ficasse em condições de ser embarcado para Porto Príncipe e, sendo assim, foi aberto voluntariado para os militares da área de saúde que quisessem embarcar para contribuir no apoio aos feridos. Seria a 
primeira vez que o hospital de campanha da Marinha, denominado de Unidade Médica Expedicionária da Marinha, seria utilizado (Brasil, 2010a).

Com o intuito de contribuir na operação de socorro ao Haiti, no dia 16 de janeiro de 2010, a Marinha italiana ofereceu o emprego conjunto à Marinha do Brasil para atuar na missão humanitária. Militares da Marinha e Servidores Civis do Ministério da Saúde do Brasil atuariam a bordo do porta aviões "CAVOUR", da Marinha Italiana. O embarque de militares e civis voluntários no navio italiano, ocorreu no dia 28 de janeiro e contribuiu para que a função logística saúde pudesse ser ativada (Vilela, 2015).

De acordo com a Nota à Imprensa do dia 28 de janeiro de 2010 (Brasil, 2010c), no porta aviões italiano também foram embarcados helicópteros Super Puma e Esquilo da Marinha do Brasil, o que contribuiu para o transporte de pessoal e material, busca e resgate e apoio às tropas em terra. Para atuar em operações dessa natureza, a opção mais usual são os helicópteros classificados como de emprego geral, que é o caso do Super Puma e do Esquilo, e que podem ser empregados em um amplo espectro de tarefas. Suas capacidades se enquadram nas principais demandas nas ações de ajuda humanitária. E, graças aos helicópteros brasileiros empregados, os militares puderam atuar em situações onde o porto estava destruído e as vias terrestres seriamente danificadas.

Visando o apoio as tropas brasileiras no Haiti e a prestação de auxílio humanitário, a Marinha do Brasil expressou ao Estado Maior da Defesa o interesse de guarnecer um escritório de Apoio Logístico e Compras na República Dominicana. Ainda no dia 17 de janeiro, a MB participou ao MD sua capacidade de prontificar um efetivo para missões de segurança naquele país (Brasil, 2010a).

Para que pudesse cumprir a missão por 60 dias no Haiti, a estimativa de custeio e investimento da Marinha totalizava R\$ 61.047.598,00 (Brasil, 2010a). Vale ressaltar que o valor apresentado não levava em consideração o pagamento de sua força de trabalho, que estimava o envio de mais 201 militares, visando um acréscimo ao efetivo da Marinha na MINUSTAH, que conta com 215 militares em cada contingente, que é substituído a cada 6 meses.

No dia 22 de janeiro, o Ministério da Defesa determinou que a Marinha do Brasil designasse um de seus meios com grande capacidade de carga e capacidade anfíbia para promover o ressuprimento à MINUSTAH, podendo incluir neste meio, caso houvesse disponibilidade, ajuda humanitária também (Brasil, 2010a). 
O transporte de material pesado e também volumoso para o Haiti nos navios anfíbios assumiram a função logística transporte para esta missão. O navio inicialmente designado pela Marinha foi o Navio de Desembarque de Carros de Combate “Almirante Sabóia”. No dia 25 de janeiro, a Marinha participou ao Ministério da Defesa que o navio estava pronto, a carga solicitada inicialmente pronta para ser embarcada, além do reforço de 201 militares prontos para se deslocarem para o Haiti (Brasil, 2010a).

Entre os dias 27 e 31 de janeiro, foi realizado o carregamento do Navio “Almirante Sabóia”. Devido à incerteza do cenário que seria encontrado por ocasião da chegada do navio no Haiti, houve a preocupação de realizar o embarque do material de maneira que, dada a chegada em Porto Príncipe, não se tivesse a necessidade de apoio externo para o desembarque. O embarque foi realizado em pallets e em contêineres, tornando a operação mais rápida, já que em cenário de desastres, o fator tempo é uma variável relevante, além de necessitar de um menor número de militares para realizar o desembarque. A viagem do Rio de Janeiro até o Haiti ocorreu entre os dias 08 de fevereiro e 17 de fevereiro, tendo o navio transportado 209,1 ton de ajuda humanitária. Cabe observar que do dia que ocorreu o terremoto até a chegada do primeiro navio com ajuda humanitária, decorreu mais de um mês (Brasil, 2010a).

Dando sequência ao fluxo logístico humanitário, o Navio “Garcia D’Avila” deslocou-se para o Haiti em 28 de fevereiro, levando a bordo cerca de 200 ton de material de ajuda humanitária, que foram embarcadas nas cidades do Rio de Janeiro, Recife e Fortaleza. Além de ajuda humanitária, também foi transportado por este navio, material para reabastecimento das tropas brasileiras, como viaturas (caminhão, ambulância e blindado), além de geradores de energia e munição diversa (Brasil, 2010a).

\section{2 .1}

\section{Análise da atuação e dificuldades encontradas no Haiti}

A população do Haiti foi demasiadamente esmagada pela escalada, magnitude e pela brusquidão da catástrofe que atingiu o país. Simplesmente não havia capacidade de responder a todas as demandas humanitárias que surgiram, especialmente se considerada a logística e as restrições de acesso que se 
apresentou no país no momento pós desastre. Após a ocorrência do terremoto, as ruas, estradas e a maioria das edificações do país ficaram obstruídas ou destruídas (Cezar, 2014).

Alguns fatores contribuíram significativamente para que o desastre no Haiti tivesse tomado a proporção em termos de gravidade que tomou, como por exemplo (Arraes, 2013; Sutter e King, 2012):

- ocorrência do terremoto em uma pequena profundidade de aproximadamente $13 \mathrm{~km}$, o que tem por efeito transmitir grande parte da energia liberada para a superfície;

- a região que foi atingida é composta principalmente por planície sedimentária, o que aumenta o movimento do terreno na superfície;

- o epicentro do terremoto foi localizado em uma região com grande densidade populacional, a cerca de $26 \mathrm{~km}$ do palácio presidencial que fica localizado no centro de Porto Príncipe, e próximo de outras cidades com áreas que se apresentam densamente povoadas; e

- a deficiente infraestrutura do país, incluindo a baixa qualidade e resistência das construções.

No que diz respeito à rede de transportes do Haiti, cerca de $70 \mathrm{~km}$ de estradas ficaram danificadas, parte do porto de Porto Príncipe ficou inoperante e o aeroporto foi severamente afetado (Haiti, 2010), o que se tratando de um ambiente em que o caos se encontra instalado deve ser considerado como de grande relevância, uma vez que é preciso que ocorra a identificação de como ocorrerá o deslocamento dos insumos a serem utilizados na assistência que será prestada, respeitando suas restrições.

A Marinha do Brasil participou ativamente das ações de ajuda humanitária desenvolvidas pelo governo brasileiro naquele país. Devido às precárias condições portuárias encontradas em Porto Príncipe, a realização de desembarque de qualquer suprimento em praias haitianas era considerada um desafio, já que a estrada de acesso as docas portuárias haviam se curvado e muitos dos guindastes que o porto possuía ficaram inclinados e com suas bases submersas. O píer principal, na parte Norte do porto foi completamente destruído e seu terminal desmoronou (USGS, 2011). Para a ação realizada pela Marinha na região, essa informação apresentou-se como fundamental pois foi baseada nela que a Força foi capaz de definir qual seria o melhor meio de transporte a ser utilizado. Por possuir 
navios com capacidade anfíbia, característica que normalmente um navio mercante não possui, um navio de guerra da Marinha do Brasil foi utilizado.

Num cenário de elevada incerteza e de enorme destruição como o encontrado no porto haitiano, a escolha da utilização de navios com capacidade anfíbia cresceu em importância. A utilização de navios com esta característica neste tipo de operação maximiza a mobilidade, versatilidade e a flexibilidade do emprego do meio, atendendo as imprescindíveis necessidades de transporte apresentadas pela Força. Este tipo de navio consegue combinar vários atributos na prestação de assistência deste tipo de ação, pois possui grande capacidade de carga e seu descarregamento é diferenciado podendo ser realizado em momento que mais se apresentar adequado e no local que for mais apropriado, uma vez que para realizar o desembarque deste meio, não é necessária nenhuma estrutura portuária.

Quando se fala de um navio com capacidade anfíbia, entende-se que a principal característica que este meio apresenta é a flexibilidade, pois trata-se de um navio de múltiplo emprego que confere versatilidade, mobilidade e capacidade de permanência da área que atua. Este tipo de navio é projetado especificamente para o transporte de grande capacidade de carga, sem necessitar de apoio externo para seu descarregamento, pois para que este seja realizado, normalmente estes navios contam com guindastes com diferentes capacidades, além de rampas de proa e popa. O fato de possuir navios com essa característica e em condições de pronto uso, permitiu que a missão de transporte e descarregamento de material no Haiti fosse realizada.

A Marinha do Brasil pode contar com dois navios, o navio Almirante Sabóia e o navio Garcia D’Avila, realizando viagens e transportando material para o Haiti. Ressaltando-se a importância de possuir navios anfíbios nesse tipo de operação, já que, em cenários de desastres, nem sempre há cais para atracação ou guindastes para realizar o desembarque de carga, e navios com essas características possuem a capacidade de se aproximarem da praia e desembarcarem em meios próprios, a ajuda necessária.

O primeiro meio que foi escolhido pela Marinha do Brasil para realizar o transporte de ajuda humanitária até o Haiti foi o navio Almirante Sabóia. A carga foi transferida para o navio em pallets ou em contêineres tornando a operação bem mais rápida e com reduzida necessidade da utilização de mão de obra externa. O 
navio transportou aproximadamente 700 toneladas de material de ajuda humanitária e também de apoio logístico necessário para as forças que já se encontravam no Haiti, entre eles: diversos gêneros não perecíveis, medicamentos e material hospitalar generalizados para socorros aos desabrigados, além de viaturas, blindados e outros suprimentos, necessários às atividades das tropas brasileiras que estavam atuando no país atingido (CCSM, 2010a).

No Haiti, um fato positivo que pode ser observado foi a coordenação de ações entre a Marinha Italiana e a Marinha do Brasil, quando ambas atuaram no navio porta aviões CAVOUR, da esquadra italiana. Ambas as equipes que se estabeleceram no porta aviões puderam realizar ações no que diz respeito a função logística Saúde (Vilela, 2015). Esta ação se deu por meio do embarque de dois helicópteros de emprego geral da Marinha Brasileira no porta aviões italiano, com uma equipe especializada em Evacuação Aeromédica. As aeronaves brasileiras operaram em conjunto com aeronaves italianas em missões principalmente de evacuação aeromédica de feridos, além de outras, como transporte de pessoal e material, busca e resgate, apoio às tropas em terra. Os destacamentos aéreos da Marinha do Brasil contaram com onze oficiais e trinta e seis praças. A equipe médica que embarcou no navio italiano era composta por seis médicos e dez enfermeiros militares. A equipe atuou em conjunto com os médicos italianos, já embarcados, em procedimentos de socorro médico às vítimas resgatadas por helicópteros de terra. O navio italiano possui um hospital de emergência que conta com trinta e cinco leitos, oito dos quais em UTI (Vilela, 2015; CCSM, 2010b).

Ainda em relação ao fato de possuir navios em condições de atuar em tais situações, observa-se a necessidade da importância da Marinha do Brasil em possuir um navio hospital oceânico, já que a participação do navio italiano “CAVOUR” teve repercussão internacional e caso a Marinha do Brasil possuísse um navio com essa especificidade poderia ter realizado uma operação similar à que foi realizada pelo meio italiano, ampliando a ajuda prestada ao Haiti e contribuindo para a projeção do Brasil, no cenário internacional.

O contingente brasileiro está no Haiti desde 2005, o que fez com que esse passasse por todas as fases do terremoto. O conhecimento sobre o terreno permitiu de certa forma ajudar a dirimir as dificuldades causadas pelo desconhecido quando se chega em um local depois que tudo foi destruído. A Marinha do Brasil teve participação efetiva em todos os momentos do desastre, pois apesar de já 
possuir tropas pelo país que já atuavam lá por conta da atuação dos militares brasileiros em contribuir com a pacificação do mesmo por meio da MINUSTAH, houve um reforço de militares que desembarcaram no Haiti, para contribuir com a ação humanitária que se fazia necessária. O fato de já possuir um contingente no Haiti foi fundamental para que a Marinha conseguisse verificar de forma mais acurada a demanda, facilitando a ajuda humanitária que devia ser prestada, tornando essa ação mais rápida e consequentemente mais efetiva. Desde o terremoto, a Força reorientou suas atividades para apoiar os esforços humanitários e o resgate a vítimas, além de contribuir para a manutenção da lei e da ordem.

Porém, alguns problemas intra-Marinha, no que se refere às aquisições, do que seria utilizado na operação puderam ser observados. Por exemplo, especificamente no caso do setor do abastecimento, a necessidade de se cumprir aspectos formais e legais nas aquisições necessárias que foi considerado uma preocupação. Questões relacionadas sobre "de onde viriam os recursos para pagamentos aos fornecedores" do material que seria utilizado no socorro aos necessitados do Haiti foram consideradas a época, já que os recursos disponíveis para Força realizar suas atividades previstas são escassos. Além disto, a operacionalização dos processos de obtenção do material que era necessário também gerou questionamentos por parte daqueles que deveriam realizar tais processos, uma vez que estas não poderiam ocorrer sem a realização de procedimentos licitatórios, já que processos de dispensa de licitação só são possíveis de serem realizadas quando ocorre a assinatura de um Decreto de calamidade pública, o que não ocorre em casos da ajuda internacional, e que mesmo assim exigem uma formalização do processo, suplantando a necessidade emergencial de disponibilizar, no tempo adequado, o material destinado a missão (Brasil, 2010a).

Outro ponto, de acordo com Brasil 2010a, a ser levantado entre os problemas intra-Marinha, foi a percepção de que as normas para execução do abastecimento dos meios que atuariam na missão não contemplaram de forma clara e objetiva como deveria se dar o abastecimento dos meios operativos em situações de crise, o que pode ser observado como um gargalo na gestão entre os stakeholders participantes do processo de abastecimento. Quando a Marinha do Brasil precisou acionar os setores logísticos que seriam necessários para esta operação humanitária, a Força não possuía na prática uma sistemática definida e 
conhecida entre todos os setores. O ciclo logístico adotado pela Força teve sua realização comprometida neste evento, pois aqueles que estavam envolvidos nele e deveriam responder as perguntas levantadas para que este se realizasse, demoraram ou não conseguiram identificar que papéis cabiam a cada um deles.

\section{3}

\section{Terremoto no Chile em 2010}

O território chileno é extremamente vulnerável a desastres naturais, principalmente por estar localizado na borda de uma placa tectônica bem próximo ao encontro das placas Sul-americanas e de Nazca, o que faz com que o país tenha muitos motivos para se preocupar com a ocorrência de desastres: tsunamis, erupções vulcânicas, inundações e, sobretudo, terremotos que ameaçam constantemente os chilenos (Yanez, 2012).

A história do Chile foi marcada constantemente por desastres naturais, já que o país está localizado no denominado “cinturão de Fogo”, como é conhecida uma série de falhas geológicas localizadas nas camadas superiores da crosta terrestre. Este cinturão se estende ao longo dos Estados banhados pelo Oceano Pacífico no continente americano, alcançando até as Ilhas Aleutas descendo pela costa do Japão, até a Nova Zelândia. Cada uma destas falhas é um ponto de encontro das placas tectônicas que compõem a crosta terrestre. Estas placas estão em constante movimento, colidindo, unindo-se ou distanciando-se entre si, e ao fazê-lo, geram uma imensa pressão em suas áreas de contato, produzindo sismos e terremotos (USGS, 2016). Exemplos disto foram os terremotos dos anos de 1960 e 2010.

A vulnerabilidade advinda da posição geográfica é reforçada pela longa costa do Chile, que possui um território marítimo maior do que sua superfície terrestre e talvez essa seja a explicação para que o país tenha construído uma forte tradição naval.

Quarenta e sete dias é o intervalo de tempo que separa a tragédia que atingiu o Haiti da que atingiu o Chile. O terremoto, considerado o segundo mais forte no país e um dos cinco mais fortes registrados no mundo inteiro (8,8 na escala Richter), cobriu uma área de 700 quilômetros, desde a cidade de Temuco até a cidade de Santiago, arrasando grande parte das cidades de Constitución, 
Concepción, Cobquecura e o porto de Talcahuano. As regiões que foram mais afetadas sofreram danos significativos em suas estradas, pontes, aeroportos, portos, serviços públicos e redes de comunicação (USGS, 2011).

O terremoto que atingiu o território chileno seguiu-se de um tsunami e, segundo a USGS (2011), atingiu ao menos seis regiões do país (mais da metade do território nacional), incluindo suas principais metrópoles, além de dezenas de cidades médias e inúmeras localidades menores da costa e do interior do país (Figura 5). Os danos mais graves ocorreram ao longo da costa e em partes do vale central do Chile, sendo as principais indústrias da região profundamente afetadas (pesca, transporte marítimo, mineração, refinarias, silvicultura, vinicultura e agricultura).

As consequências decorrentes destes eventos causaram substanciais perdas de infraestrutura em áreas próximas ao epicentro. Houve corte total de energia elétrica da área coberta pelo Sistema Interconectado Central, que fornece energia desde a cidade de Taltal, na região de Antofagasta, até a Isla Grande de Chiloé. Na ausência de energia elétrica, o país ficou sem comunicação na rede de telefones fixos e de celulares, produzindo longa pausa nas comunicações das estações rádio. Foram afetados os sistemas de água potável, redes de esgoto e de descargas de águas residuais e as estações de tratamento em áreas urbanas e rurais (USGS, 2011).

Devido à amplitude da catástrofe, uma enorme força de trabalho foi empregada em todo o país por ocasião no socorro a ser prestados aqueles que necessitavam. Esta força de trabalho apresentava diferentes experiências e foi devidamente distribuída de acordo com a necessidade demonstrada. Diversas organizações nacionais, internacionais e não governamentais estiveram presentes no esforço de socorro, no terremoto que assolou o Chile, entre elas estavam principalmente vários grupos de resgate, instituições civis e militares de países amigos, entre estes, o Brasil (USGS, 2011 e OPAS, 2010). 


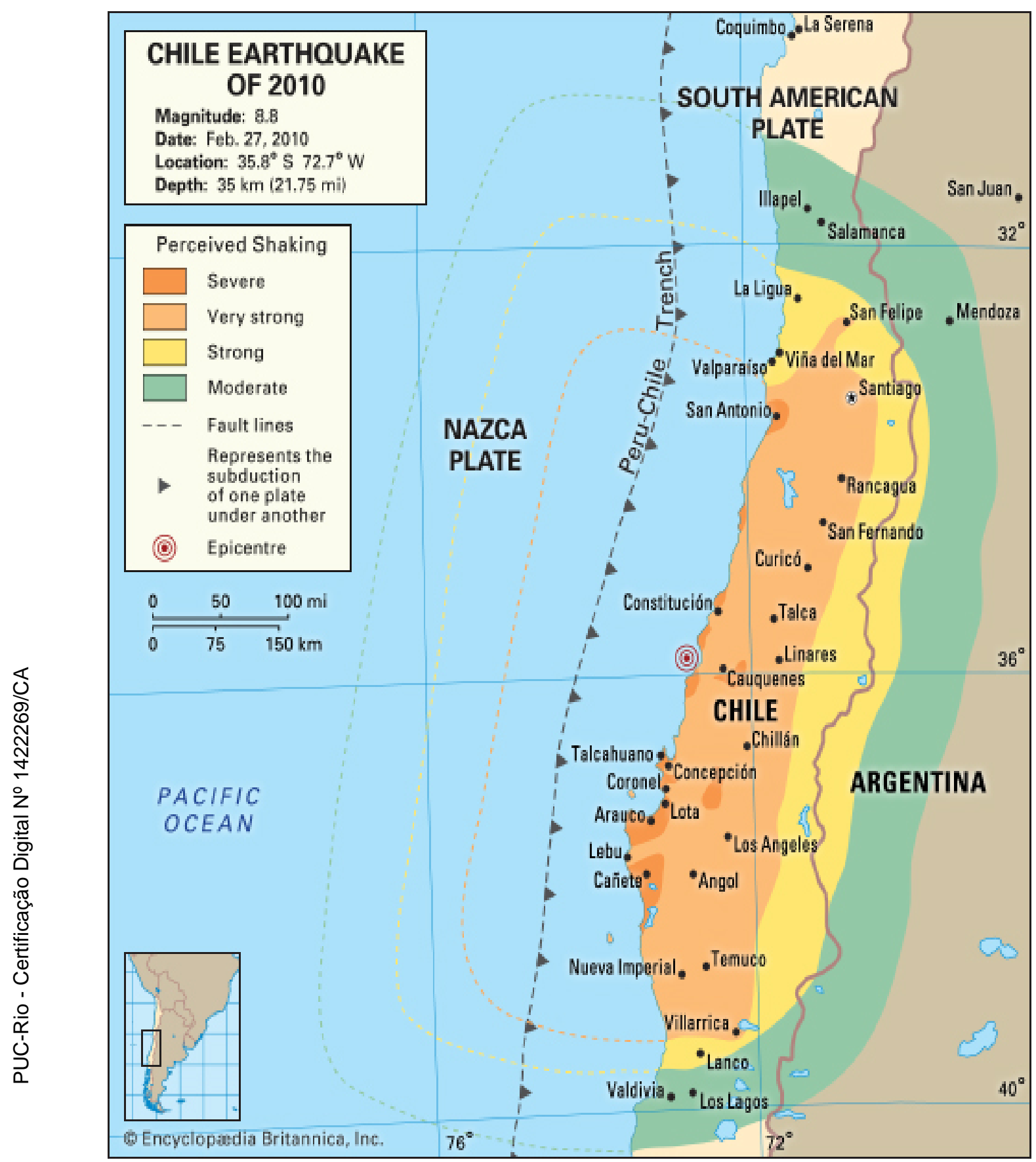

Figura 5: Intensidade do tremor nas áreas atingidas do Chile pelo terremoto de 2010 (Pallardy e Rafferty, 2016).

A ajuda humanitária foi prestada ao Chile através de instalações e pessoal de saúde, além de hospitais militares. Na maioria dos casos, a força militar chilena garantia a segurança destas instalações e fazia as coordenações necessárias com a autoridade de saúde da região em que esta foi implantada.

A Tabela 4 apresenta um resumo dos danos e perdas para o Chile, no terremoto, acompanhado de tsunami, de 27 de fevereiro de 2010: 
Tabela 4: Resumo de danos e perdas, no terremoto de 27 de fevereiro de 2010 - Chile (USGS, 2011).

\begin{tabular}{|l|l|}
\hline Mortos & 521 pessoas \\
\hline Desaparecidos & 56 pessoas \\
\hline Casas destruídas & Aproximadamente 370.000 \\
\hline Hospitais destruídos & 73 \\
\hline Escolas destruídas & 3.049 \\
\hline Pontes destruídas & 221 \\
\hline $\begin{array}{l}\text { Vilas rurais e comunidades costeiras } \\
\text { afetadas }\end{array}$ & Mais de 900 \\
\hline Perdas econômicas estimadas & US\$ 30 bilhões, 17\% do PIB \\
\hline
\end{tabular}

No Chile, por tratar-se de um país onde as organizações estão mais bem preparadas para atuar em casos de desastres, a ajuda humanitária internacional, que lá precisou atuar a fizeram apenas com efeito de complementar as nacionais que já estavam atuando. A participação da Marinha do Brasil no auxílio ao Chile foi distinta daquela que ocorreu no Haiti, pois no caso do Chile a determinação foi de envio de um Hospital de Campanha (HCamp) para trabalhar em socorro de emergência e a unidade de saúde mobilizou-se em 48 horas, e foi transportada para o local da catástrofe por aviões da Força Aérea Brasileira (FAB). Para o transporte desta unidade hospitalar, foram necessários seis voos da aeronave “Hércules” (Vilela, 2015).

Esse hospital de campanha que foi instalado em uma região mais periférica próxima a cidade de Santiago, denominada de Cerro Navia, e contou com um efetivo total de 102 militares brasileiros, entre médicos e profissionais de outras áreas de apoio a saúde. O Hospital de Campanha que foi utilizado no Chile tinha capacidade para realizar cerca de 400 atendimentos diários e possuía autonomia para operar por trinta dias, com todos os tipos de suprimentos que se fizessem necessários. Esse hospital, realizou mais de 12.000 atendimentos em 41 dias de atuação, no país (CCSM, 2010c, d; Gonçalves Pinto, 2010). 


\subsection{1}

\section{Análise da atuação e dificuldades encontradas no Chile}

Os fortes códigos de construção do Chile salvaram muitas vidas durante o terremoto de 2010 e são provavelmente fatores significativos da baixa mortalidade apresentada pelo país em casos de desastres semelhantes a esse (Mora e Brain, 2013). Porém, mesmo possuindo essa experiência, o país se vê obrigado a melhorar continuamente sua estratégia de prevenção e resposta com o objetivo de minimizar o impacto de desastres naturais junto a sua população (Yanez, 2012).

Como já foi dito, a participação da Marinha do Brasil no socorro ao Chile se deu por meio do envio de um Hospital de Campanha. Inicialmente, este hospital seria instalado na cidade de Concepción, uma das mais afetadas pela tragédia, porém, momentos antes da decolagem das aeronaves da Força Aérea Brasileira que transportariam o hospital, decidiu-se pela instalação deste na região de Cerro Navia, nos arredores de Santiago, esta mudança deveu-se ao fato de apesar de Concepción ter sido bastante afetada, a mesma já estava sendo atendida pela instalação de outros hospitais de campanha, enquanto que a região de Cerro Navia que teve quatro grandes hospitais destruídos, ainda apresentava uma maior necessidade de atuação médica. (Vilela, 2015). Esta mudança evidência a importância da flexibilidade logística necessária para a realização deste tipo de operação.

As barracas de campanha utilizadas para compor o Hospital de Campanha brasileiro, instalado no Chile, se apresentaram inadequáveis para o clima frio encontrado no país. O ideal, no caso da atuação do hospital de campanha da Marinha, em operações pós desastre seria torná-lo mais flexível e adaptável para situações onde há incapacidade de prestação de serviço regular de saúde, seja público ou privado. O hospital de Campanha enviado para o Chile possuía condições de atuar no atendimento de primeiros socorros; tratamento de doenças comuns e infecciosas; realização de três a quatro cirurgias por dia (com anestesia) e realização de ressuscitações emergenciais (Vilela, 2015; Gonçalves Pinto, 2010).

No dia 17 de março, representantes do Ministério da Saúde do Chile visitaram as instalações do hospital de Campanha utilizado pela Marinha do Brasil. A comitiva percorreu as diversas barracas do HCamp, constatando a 
qualidade do atendimento e a satisfação dos pacientes na atenção prestada pela equipe de saúde brasileira aos que necessitavam de ajuda (CCSM, 2010d).

\section{4}

\section{Comparativo entre os dois eventos}

Diante da semelhança entre os dois eventos, é possível compará-los e também as ações que foram realizadas nos dois países aqui estudados além de observar algumas similaridades, entre eles, como por exemplo, as dificuldades encontradas nos momentos iniciais devido ao caos generalizado encontrado, em menor escala no Chile e em maior no Haiti, e a desorganização decorrente do desastre nas estruturas locais. A Tabela 5, apresenta uma comparação sucinta entre os dois terremotos e a atuação da Marinha do Brasil.

Apesar da intensidade do terremoto que atingiu o Chile ter superado a intensidade daquele que atingiu o Haiti, na escala Richter, o país se apresentou muito mais bem preparado. O Chile, diferentemente do Haiti, possui uma grande experiência em terremotos, que afetam indiscriminadamente a vida das pessoas, a infraestrutura existente no país e os serviços básicos instalados (Vilela, 2015; Yanez 2012).

Quando comparadas as ações empreendidas pela Marinha e o tipo de apoio requerido e necessitado nos dois eventos, nota-se que o grau de preparação da Nação que é atingida por um terremoto ditará o quanto esta é capaz de sobreviver, prosperar e se reconstruir após o evento. Apesar da magnitude do terremoto que atingiu o Chile ter sido superior ao que atingiu o Haiti, visto pelo número de vítimas fatais e destruição de infraestrutura do país, este se apresentou mais eficiente em termos de cultura em lidar com eventos catastróficos que o segundo, necessitando inclusive de um menor apoio humanitário externo, já que o Chile apresenta instituições mais bem preparadas para lidar com tal emergência. O resultado deste melhor preparo em lidar com estas situações facilitou e melhorou a aplicação de recursos pouco disponíveis, tornando a logística a ser realizada pelas próprias instituições chilenas mais simples e eficiente.

Em relação às ações de apoio desenvolvidas pela Marinha nos dois países, observa-se que aquelas realizadas no Haiti exigiram um esforço logístico muito superior aquelas que foram empregadas no evento relacionado ao Chile, já que no 
Haiti necessitou-se de uma maior quantidade de mão de obra a ser empregada, e uma maior disponibilidade das organizações militares que atuaram, demandando da logística da Força uma atuação mais elaborada.

Tabela 5: Comparação entre os dois eventos.

\begin{tabular}{|c|c|c|}
\hline & Haiti & Chile \\
\hline Número de mortos & $\begin{array}{c}\text { Aproximadamente } 300 \\
\text { mil }\end{array}$ & 521 \\
\hline $\begin{array}{l}\text { Comprometimento do PIB, em } \\
\text { decorrência do desastre }\end{array}$ & $66 \%$ & $17 \%$ \\
\hline Qualidade das construções & Má qualidade & Construções rígidas \\
\hline Área & Atlântico & Pacífico \\
\hline Magnitude (escala Richter) & 7,3 & 8,8 \\
\hline Profundidade do Epicentro & $10 \mathrm{Km}$ & $35 \mathrm{Km}$ \\
\hline Tsunamis & Não & Sim \\
\hline $\begin{array}{c}\text { Presença de militares brasileiros, no } \\
\text { momento do desastre }\end{array}$ & $\begin{array}{c}\text { Contingente brasileiro } \\
\text { instalado no País }\end{array}$ & $\begin{array}{c}\text { Sem a presença de } \\
\text { militares }\end{array}$ \\
\hline $\begin{array}{l}\text { Quantidade de militares da Marinha } \\
\text { do Brasil atuando, por ocasião da } \\
\text { ajuda humanitária }\end{array}$ & Cerca de 900 & 102 \\
\hline $\begin{array}{c}\text { Principal tipo de apoio prestado } \\
\text { pela Marinha }\end{array}$ & $\begin{array}{c}\text { Segurança e transporte de } \\
\text { carga }\end{array}$ & $\begin{array}{l}\text { Instalação de } \\
\text { Hospital de } \\
\text { Campanha }\end{array}$ \\
\hline $\begin{array}{l}\text { Meios de transporte utilizados pelos } \\
\text { militares brasileiros }\end{array}$ & Navios Anfíbios & $\begin{array}{c}\text { Aeronaves da Força } \\
\text { Aérea Brasileira }\end{array}$ \\
\hline
\end{tabular}

Percebe-se que a participação da Marinha do Brasil no evento ocorrido no Chile foi mais facilitada, uma vez que o país sabia do que necessitava, ficando a atuação da Força mais direcionada às atividades relacionadas a apoio em áreas de saúde, diferente do Haiti, onde as estruturas já eram deficientes e a necessidade de enfrentar um desastre agravou suas condições, necessitando de apoio, por parte dos militares brasileiros, com material a ser deslocado para que as equipes de resgate atuassem, e de mão de obra especializada para atuar na segurança e no atendimento médico aos feridos. 
A prestação do apoio humanitário internacional necessário pode ser encarada como um enorme desafio logístico a ser vencido por uma organização como a Marinha do Brasil, pois a realização de qualquer ação com este caráter exige prontidão, disponibilidade, inter-relacionamento e flexibilidade no preparo técnico e operacional nas diversas funções logísticas em que a Força atua, para que o mesmo possa ser alcançado. Algumas questões só são levantadas na hora em que nos deparamos com os problemas, porém vale lembrar que outras devem ser consideradas básicas e devem estar incluídas na cultura da organização. Processos que envolvam abastecimento de diversos suprimentos dos meios a serem utilizados precisam ser desenvolvidos para que na necessidade de sua aplicação, esta ocorra sem atrasos ou de maneira ineficiente.

\section{5}

\section{Desafios a serem superados e lições aprendidas}

A partir da apresentação destes dois eventos pode ser observado que Estados sujeitos a desastres naturais, caso do Haiti e do Chile, devem implementar estratégias de gestão de riscos centradas não somente na reação a este tipo de situação, mas principalmente na prevenção, já que uma vez que o desastre natural é inevitável, os efeitos sentidos por suas populações podem ser minimizados se os que atuarem estiverem prontos para tal. Isto exige das autoridades uma avaliação cuidadosa das vulnerabilidades relacionadas aos diferentes tipos de desastres naturais possíveis de ocorrer, para, a partir dessa avaliação, estabelecer as medidas de prevenção ou redução dos riscos e, quando isto não for possível, reduzir os danos que causam.

As duas tragédias aqui descritas puderam pôr, sob o enfoque da Força aqui estudada que é a Marinha do Brasil, a evidência que desafios de caráter logístico e legislativos apresentam um espaço significativo a ser preenchido, para que a sua participação no futuro em eventos semelhantes ocorra de forma harmônica, eficiente e dentro do previsto em termos de legislação, uma vez apresentada ao problema, para que a Força e todos os seus sistemas integrantes saibam como agir.

Como lição a ser aprendida pela logística da instituição, vale ressaltar que o elemento crítico neste tipo de operação é o tempo. Sendo assim, é importante que a Força considere a possibilidade de adotar estratégias de abastecimento onde, 
caso não seja possível preparar-se antecipadamente a estes (já que os processos de obtenção dos suprimentos a serem utilizados em casos semelhantes aos aqui estudados iniciam-se imediatamente depois do desastre e no caso da Administração Pública Federal, da qual a Marinha faz parte, estes processos de obtenção exigem procedimentos legais específicos que podem demandar muito tempo), que ao menos suas ações para atendê-los sejam ágeis, adaptáveis e alinhadas às necessidades que surjam. Desta forma, faz-se com que a determinação das necessidades não seja comprometida em termos de eficiência, qualidade e tipo de suprimento a ser utilizado. Isto foi evidenciado no caso do Haiti, quando o primeiro navio que chegou ao país para prestar apoio levou mais de trinta dias a contar do dia do desastre. Para melhorar este aspecto de determinação de necessidades, a Marinha americana, por exemplo, recorre à elaboração de cenários possíveis, que embora produzam resultados bastante imprecisos, proporcionam à Força a capacidade de melhor lidar com situações novas caso estas de fato ocorram, reduzindo o impacto de um acontecimento que não havia sido considerado anteriormente (EUA, 1999).

Tão logo uma tragédia ocorra, a mobilização militar no cenário permite a restauração da ordem pública possibilitando a realização de ações que forneçam apoio as comunidades afetadas nas tarefas de estabilização e normalização num primeiro momento e reconstrução nos momentos que se seguem. Os militares apresentam condições básicas de apoiar a população civil em atividades logísticas específicas como, por exemplo, saúde e transporte, permitindo que se chegue o alívio mais rapidamente as pessoas afetadas.

Sendo assim, e levando em consideração o desenrolar da atuação da Marinha do Brasil nos dois eventos aqui estudados, as lições aprendidas com os desastres de 2010 é que a Força tão logo receba a determinação de atuar em cenários deste tipo de desastres naturais deve estar preparada para realizar tarefas relacionadas ao socorro e atendimento médico a pessoas, considerando sua capacidade operacional de permanecer na área de operações com uma logística própria, caso da instalação do hospital de Campanha no Chile, ou de transportar ajuda, como foi prioritariamente o caso no Haiti. É necessário que dentro dos setores da Marinha que se relacionam para prestar apoio, estes entendam minimamente seus papéis e possam aplicar os ensinamentos adquiridos no caso do acontecimento de eventos semelhantes aos aqui estudados, preparando melhor 
seus stakeholders para que no trabalho em conjunto estes estejam capacitados a atuarem de forma antecipada aos desafios da demanda que se apresentam no cenário, limitando efeitos que dificulte o desenrolar do trabalho.

A flexibilidade no planejamento de ações, prevista na sistemática PROA, e a antecipação prévia e mínima de suprimentos utilizados pelos meios da Marinha, também prevista nesta sistemática, talvez tivesse permitido uma atuação mais rápida e eficiente da Força nos casos aqui estudados.

Além disso, outra lição a ser ressaltada é em relação à sua capacidade de transporte, que deve ser tratada como sensível devido ao benefício de possuir navios com características que permitam o deslocamento de grandes quantidades de ajuda humanitária e facilidade de carga e descarga, mesmo em ambientes em que o caos está instalado, caso dos navios utilizados no apoio ao Haiti.

Vale lembrar que o uso da Força não precisa estar limitado às fases iniciais do desastre, já que esta pode continuar apoiando o país afetado por um desastre na busca pela restauração das condições normais da população através da implantação de várias tarefas de reconstrução se assim se fizer necessário, como fica claro para o caso do Haiti, que teve sua já fragilizada infraestrutura destruída. A dificuldade aqui encontrada é ser capaz de definir até que ponto os militares empregados nesta restauração devem seguir auxiliando a região afetada pela tragédia.

Em relação ao previsto na legislação atualmente aplicada no Brasil, a Lei $\mathrm{n}^{\circ}$ 8.666/93, só prevê dispensa de licitação para materiais e serviços a ser utilizado pelos contingentes militares, o que por vezes causa confusão com material e serviço a ser adquirido para ajuda humanitária. Ou seja, vale a pena observar a necessidade de desenvolvimento de novos estudos que mostrem a necessidade de implantação de uma legislação que permita a criação de mecanismos legais de dispensa de licitação que possibilitem a atuação das Forças Armadas em ajuda humanitária com o mínimo de interferência que dificulte seu trabalho junto a população afetada, para que a demanda inesperada, possa ser atendida sem maiores impedimentos legais. 


\section{Conclusões}

Operações humanitárias exigem um planejamento especial e um enorme nível de flexibilidade para que o esforço logístico a ser utilizado nestas se apresente o mais eficiente possível. Isso permitirá a execução do trabalho realizado, seja por militares ou civis, de reduzir o sofrimento daqueles que necessitam. A relevância neste planejamento ganha maior substância quando se trata de desastres naturais, que muitas vezes tem sua ocorrência de forma inesperada e afeta de forma indiscriminada os residentes de um país ou região, instalando por vezes o caos no ambiente.

No que se refere à logística que deve ser desenvolvida e aplicada, para esse tipo de situação, o desafio de abastecer os militares com todos os suprimentos que se fazem necessários, quando solicitados para realizarem operações de ajuda humanitária, fomenta a necessidade do desenvolvimento e aprimoramento de soluções que tornem o apoio para a execução de suas ações mais eficiente.

O estudo aqui apresentado, pautou-se inicialmente, numa revisão bibliográfica de conceitos e doutrinas militares e civis, considerados relevantes para a análise do problema levantado, além da apresentação, análise e comparação de dois eventos internacionais recentes em que a Marinha do Brasil atuou (terremotos ocorridos no Haiti e no Chile, no ano de 2010) com seus meios e também recursos humanos, sendo apoiada pelos principais sistemas que compõem a Força. A partir desta apresentação, foi descrito como ocorre a atuação da logística dentro da Força e como esta tem sua aplicação, tomando por bases as doutrinas legais que regem esta aplicação.

A partir da revisão da literatura aqui realizada, da apresentação de como a logística na Marinha se desenvolve e sua execução por meio de sistemáticas de abastecimento próprias adotadas e da exposição dos dois eventos aqui estudados, os objetivos traçados nesta pesquisa foram alcançados, uma vez que o objetivo principal é o de apresentar por meio de pesquisa documental e bibliográfica os desafios enfrentados pela Marinha do Brasil em operações humanitárias realizadas pela Força por ocasião dos terremotos ocorridos no Haiti e no Chile, 
principalmente no que se refere as competências operacionais e aspectos logísticos, este foi cumprido do decorrer do estudo.

Em relação aos objetivos específicos, considera-se que estes também foram cumpridos, uma vez que a pesquisa tratou de apresentar as duas participações da Marinha, no Haiti e no Chile, em operações de ações de assistência humanitária, sendo esta apresentação baseada nas doutrinas que regem a instituição nos aspectos logísticos de disponibilidade e flexibilidade envolvidos nessas operações, além de apresentar uma análise de como ocorreu a atuação da Força em cada um dos eventos, uma comparação entre as duas atuações, e as lições aprendidas em cada um deles.

As organizações militares no Brasil costumam ser solicitadas para atuarem em apoio a eventos decorrentes de desastres nacionais e internacionais, ou seja, atuado em ambientes totalmente inóspitos, com recursos escassos ou até mesmo inexistentes. Na grande maioria dos casos em que é acionada, as Forças Armadas brasileiras cumprem papéis fundamentais nessas operações, que vão muito além do de fornecer segurança para que outras organizações realizem seus trabalhos. A partir de observações realizadas em diversas fontes diferentes, é notório o quanto é fundamental, com seu modo de atuação próprio, a atuação de agentes militares em missões humanitárias.

Fruto do papel mais atuante do Brasil em ações humanitárias internacionais e baseada nas doutrinas que regem a atuação nessas ações, a Marinha do Brasil precisa antever as necessidades mínimas necessárias para casos de desastres, permitindo uma previsão logística que possa contribuir sobremaneira como solução antes que os fatos ocorram, tornando mais eficiente dentro da atuação da Marinha do Brasil, a aplicação do que atualmente é proposto pela sistemática PROA, e possibilitando a incorporação de melhorias em processos de gestão a serem utilizados. Reitera-se que na época em que os eventos que aqui foram estudados, a sistemática PROA ainda não tinha sido implantada pela Força, ficando limitado ao nível de suposição como seria sua contribuição.

Em relação aos processos de obtenção do que é utilizado em missões humanitárias, reforça-se a necessidade de propostas que flexibilizem os diplomas legais brasileiros atualmente existentes, viabilizando maior eficiência destes pois, nas aquisições de suprimentos a ser utilizado na prestação da ajuda humanitária, não há previsão legal para que estas possam ser realizadas sem o devido processo 
de dispensa de licitação, o que demanda um intervalo de tempo considerável, fator precioso nessas situações.

Esta pesquisa também abordou a necessidade de uma melhor comunicação entre os stakeholders que atuam na logística da Marinha, uma vez que esta possui como característica de compra a forma descentralizada, por vezes e outras vezes, centralizada, o que se não for bem gerenciada, o que num primeiro momento pode ser visto como uma vantagem operacional de flexibilidade, num segundo, pode acarretar em desperdício de tempo e recursos públicos em operações do tipo que aqui foram tratadas.

Ao final desta pesquisa e de todas as análises aqui realizadas, o obtido é a proposta de contínua análise e compreensão dos processos já existentes, para que o aprimoramento destes seja a meta perpetuamente almejada pela Marinha do Brasil por ocasião de seu envolvimento em ações que sejam caracterizadas por cunho humanitário. A apresentação das duas atuações aqui tratadas, propõe novos estudos para o futuro que busquem introduzir o aperfeiçoamento em processos de levantamento de necessidades, como forma de reduzir o tempo de resposta e otimizar com um grau mínimo de previsibilidade o gerenciamento da cadeia logística em apoio nas operações de caráter humanitário, apoiando as decisões gerenciais de estoque, determinação de necessidades, obtenção e distribuição, além do fomento a novas pesquisas, externamente e internamente à Marinha do Brasil, acerca do assunto buscando principalmente o alívio do sofrimento humano, e entendendo que esta busca não pode encontrar como barreira intransponível a legislação atualmente aplicada e nem a revisão de processos. Tendo como foco a visão de futuro pela busca por um melhor nível de aprestamento logístico da Força permite que os militares que compõem a Marinha do Brasil em todos os níveis de atuação criem valor para a instituição e sobretudo para o Brasil.

Cabe ressaltar aqui que o desenvolvimento e o aprimoramento de sistemáticas como a PROA, e a proposta de novas a serem idealizadas e implantadas dentro do Sistema de Abastecimento da Marinha do Brasil é viável sob os pilares de discussão em que a instituição está baseada, que são a hierarquia e a disciplina.

Oportunidades no desenvolvimento de pesquisas futuras surgem a partir da discussão da atuação das Forças Armadas em ações humanitárias, seja no setor acadêmico ou no setor militar. Algumas delas são a análise do papel a ser dado 
para que as Forças Armadas desempenhem ações humanitárias; análise do papel da logística aplicada pelas Forças Armadas brasileiras em ações humanitárias; propostas de aprimoramento do ciclo logístico atualmente aplicado pela Marinha do Brasil no atendimento das necessidades oriundas de desastres; e especificação de como a atuação das Forças Armadas em ações humanitárias pode ser dar para que não ocorra intervenções que ultrapassem limites diplomáticos estabelecidos. 


\section{Referências Bibliográficas}

AGUILAR, S. Emerging powers, humanitarian assistance and foreign policy: the case of Brazil during the earthquake crisis in Haiti. International Journal of Humanities and Social Science, v. 2, n. 19, p. 93-101, out. 2012.

ALTAY, N.; GREEN, W. OR/MS research in disaster operations management. European Journal of Operational Research, v. 175, n. 1, p. 475493, nov. 2006.

AQUINO, T.T.B. A logística nas operações de paz: os fuzileiros navais na MINUSTAH: lições e aprimoramentos. Rio de Janeiro, 2008. Monografia Escola de Guerra Naval (EGN).

ARRAES, E.F. Desastres e desenvolvimento: o caso do Haiti. Revista VITAS Visões Transdisciplinares sobre Ambiente e Sociedade, ano III, n. 7, ago. 2013.

ARTIAGA, R.R.G. O Brasil e a intervenção humanitária no Haiti, MINUSTAH: 2004 a 2011. Rio de Janeiro, 2012. 107 p. Dissertação (mestrado) Universidade Federal do Rio de Janeiro.

AVERSA, C.E.M. A arquitetura internacional para o apoio ao Haiti no pósterremoto e a participação de forças militares nessa operação. Rio de Janeiro, 2011. 84 p. Monografia - Escola Superior de Guerra (ESG).

BALCIK, B.; BEAMON, B.M.; KREJCI, C.C.; MURAMATSU, K.M.; RAMIREZ, M. Coordination in humanitarian relief chains: Practices, challenges and opportunities. International Journal of Production Economics, v. 126, n. 1, p. 22-34, jul. 2010.

BALLOU, R.H. Gerenciamento da Cadeia de Suprimentos: planejamento, organização e logística empresarial. 4 ed. Porto Alegre: Bookman, 2001. 532 p.

BARBOSA, M.J. P. Estudo de viabilidade de implantação de RFID no armazém do Depósito de subsistência da Marinha no Rio de Janeiro. Rio de Janeiro, 2011. 130 p. Dissertação (mestrado) - Pontifícia Universidade Católica do Rio de Janeiro.

BRASIL. Constituição da República Federativa do Brasil. Senado Federal, Brasília, 1988.

Lei Federal $n^{\circ}$ 8666, de 21 de junho de 1993. Institui normas para licitações e contratos da Administração Pública. Congresso Nacional, Brasília, 1993.

Lei Complementar $n^{0}$ 97, de 9 de junho de 1999. Dispõe sobre as normas gerais para a organização, o preparo e o emprego das Forças Armadas. Congresso Nacional, Brasília, 1999. 
. Ministério da Defesa. Diretriz Ministerial $n^{\circ}$ 004, de 29 de junho de 2001. Emprego das Forças Armadas em Defesa Civil. Brasília, 2001.

. Marinha do Brasil. Estado-Maior da Armada. Manual de Logística da Marinha - EMA 400 (2 ${ }^{\mathrm{a}}$ rev.). Brasília, 2003.

Ministério da Defesa. Portaria Normativa $n^{0}$ 1890/MD, de 29 de dezembro de 2006. Política de Logística de Defesa: PLD. Brasília, 2006.

Ministério da Defesa. Marinha do Brasil. Relatório da Marinha sobre a ajuda humanitária ao Haiti. Ofício externo ${ }^{\circ}$ 40-478/2010, do Estado-Maior da Armada ao Gabinete de Segurança Institucional da Presidência da República. Anexo 11, Brasília, jun. 2010a.

Ministério da Defesa. Nota à Imprensa $\mathbf{n}^{\circ}$ 3: terremoto no Haiti. Brasília: Assessoria de Comunicação Social, 13 jan. 2010b.

Ministério da Defesa. Marinha do Brasil. Nota à Imprensa: Operação conjunta entre as marinhas do Brasil e da Itália no Haiti. Brasília: Centro de Comunicação Social da Marinha, 28 jan. 2010c.

Ministério da Defesa. Livro branco de defesa nacional (LBDN). Brasília, 2012. 276 p.

Decreto Legislativo $\mathrm{n}^{0}$ 373, de 25 de setembro de 2013. Política Nacional de Defesa: PND. Congresso Nacional, Brasília, 2013a.

Decreto Legislativo $\mathrm{n}^{\circ}$ 373, de 25 de setembro de 2013. Estratégia Nacional de Defesa: END. Congresso Nacional, Brasília, 2013b.

Marinha do Brasil. Estado-Maior da Armada. Doutrina Básica da Marinha - EMA 305 (2ª rev.). Brasília, 2014.

Ministério da Defesa. Portaria Normativa $n^{\circ}$ 40/MD, de 23 de junho de 2016. Doutrina de Logística Militar - MD 42 - M - 02 (3ª ed.). Brasília, 2016a.

Ministério da Defesa. Portaria Normativa $n^{\circ}$ 7/GAP/MD, de 13 de janeiro de 2016. Instruções para emprego das Forças Armadas em apoio à Defesa Civil. Brasília, 2016b.

BRAZ, M.A.L. A logística militar e o serviço de intendência: uma análise do programa excelência gerencial do Exército Brasileiro. Rio de Janeiro, 2004. 119 p. Dissertação (mestrado) - Fundação Getúlio Vargas.

BURKLE, F.M. Anatomy of an ambush: security risks facing international humanitarian assistance. Disasters, v. 29, n. 1, p. 26-37, mar. 2005.

CAMPBELL, A. Stakeholders: the Case in favour. Long Rang Planning, London, v. 30, n. 3, p. 446-449, jun. 1997.

CAUCHICK MIGUEL, P.A. Estudo de caso na engenharia de produção: estruturação e recomendações para sua condição. Produção, São Paulo, v. 17, n. 1, p. 216-229, jan.-abr. 2007.

CAZUMBA, R.A. As missões de paz e os atores militares e humanitários: uma abordagem sob a ótica dos conceitos de habitus e campo. Rio de Janeiro, 2012. 42p. Monografia - Escola de Guerra Naval (EGN). 
CENTRO DE COMUNICAÇÃO SOCIAL DA MARINHA (CCSM). Ajuda humanitária ao Haiti. NOMAR, ano XLVI, n. 814, p. 5, Brasília, fev. 2010a.

CENTRO DE COMUNICAÇÃO SOCIAL DA MARINHA (CCSM). Marinha participa da ajuda humanitária ao Haiti. NOMAR, ano XLVI, n. 813, p. 6-7, Brasília, jan. 2010b.

CENTRO DE COMUNICAÇÃO SOCIAL DA MARINHA (CCSM). Hospital de Campanha da Marinha presta atendimento às vítimas do terremoto no Chile. NOMAR, ano XLVI, n. 815, p. 3, Brasília, mar. 2010c.

CENTRO DE COMUNICAÇÃO SOCIAL DA MARINHA (CCSM). HCamp finaliza atendimento no Chile. NOMAR, ano XLVI, n. 816, p. 6, Brasília, abr. 2010d.

CEZAR, P.A.S. Logística humanitária: a atuação do Exército Brasileiro no Haiti pós sismo de 2010. Brasília, 2014. Monografia - Universidade de Brasília.

CHILE. Ministério de Defensa Nacional. Libro de la Defensa Nacional de Chile 2010. [S. 1.], 2010. Disponível em: <http://www.defensa.cl/libro-de-la-defensanacional-de-chile/libro-de-la-defensa-2010/> . Acesso em: 15 dez. 2016.

CHING, H.Y. Gestão de estoques na cadeia de logística integrada: Supply Chain. 4a edição. São Paulo: Editora Atlas S.A., 2010.

CLAUSEWITZ, C.V. Da Guerra. Alemanha, 1832. Disponível em: $<$ https://www.egn.mar.mil.br/arquivos/cepe/DAGUERRA.pdf $>$. Acesso em: 17 fev 2017.

COUNCIL OF SUPPLY CHAIN MANAGEMENT PROFESSIONALS. Supply Chain Management Terms and Glossary. [S. 1.], ago. 2013. Disponível em: $<$ http://cscmp.org/imis0/CSCMP/Educate/Online_Courses/CSCMP/Educate/>.

Acesso em 30 set 2016.

DA ROSA, P.R.S.; BANDEIRA, R.A.M. A coordenação civil - militar na logística humanitária e o papel das Forças Armadas Brasileiras no gerenciamento de desastres. Revista Produção Online, v. 16, n.3, p.895-915, 2016.

DAVIDSON, L.W.; HAYES, M.D.; LANDON, J.J. Humanitarian and Peace Operations: NGOs and the Military in the Interagency Process. [S. 1.]: NDU Press Book, 1996.

DIAS, A.J.F. A participação das forças armadas no haiti pósterremoto 2010. Rio de Janeiro, 2011. 59 p. Monografia - Escola Superior de Guerra (ESG).

ELLEMAN, B.A. Waves of hope: the U.S. Navy's response to the tsunami in Northern Indonesia. New Port, RI: Naval War College Press, 2007.

ESTADOS UNIDOS DA AMERICA (EUA). Headquarters Department of the Army. FIELD MANUAL 4-95: logistics operations. Washington, DC, 2014. Disponível em: <https://armypubs.us.army.mil/ProductMaps/PubForm/FM.aspx>. Acesso em: 21 fev. 2017. 
ESTADOS UNIDOS DA AMERICA (EUA). Federal Emergency Management Agency (FEMA). The Stafford Act: Disaster Relief and Emergency Assistence. Washington, DC, abr. 2013.

ESTADOS UNIDOS DA AMÉRICA (EUA). Marine Corps. MCWP 4-1: logistics operations. Quantico, VA. Marine Corps Combat Development Comand, 1999.

FREEMAN, E. Strategic management: a stakeholder approach. Boston: Pitman, 1984.

FONTAINHA, T.C.; LEIRAS, A.; BANDEIRA, R.A.M.; SCAVARDA, L.F.; Public - Private - People Relationship Stakehoder Model for disaster and humanitarian operations. International Journal of Disaster Risk Reduction. Disponível em: < http://dx.doi.org/10.1016/j.ijdrr.2017.02.004/>. Acesso em: 11 abr 2017.

FONTOURA, P.R.C.T. O Brasil e as operações de manutenção da paz das Nações Unidas. Brasília, IRBr e FUNAG, 2005. 448 p.

GLOBAL HUMANITARIAN ASSISTENCE (GHA). Counting the cost of humanitarian aid delivered through the military, [S.l.], Mar. 2013. Disponível em: <http://www.globalhumanitarianassistance.org/report/counting-the-cost-ofhumanitarian-aid-delivered-through-the-military/>. Acesso em: 17 fev. 2017.

GONÇALVES PINTO, E. Telerradiolgia no sistema de saúde da marinha: necessidades e aplicação. Rio de Janeiro, 2010. Monografia - Escola de Guerra Naval (EGN).

HAITI. Haiti Earthquake PDNA: assessment of damage, losses, general and sectoral needs. Porto Príncipe: Government of the Republic of Haiti, mar. 2010.

HAITI GRASSROOTS WATCH. Haiti Earthquake by the numbers. jan. 2011. Disponível em: <http://haitigrassrootswatch.squarespace.com/5chiffresen>. Acesso em: 20 fev. 2017.

HOWDEN, M. How humanitarian logistics information systems can improve humanitarian supply chains: a view from the field. In: 6th International ISCRAM Conference, Gothenburg, Sweden, 2009. Proceedings... Gotemburgo, mai. 2009.

HOLGUÍN-VERAS, J.; JALLER, M.; VAN WASSENHOVE, L. N.; PÉREZ, N.; WACHTENDORF, T. On the unique features of post-disaster humanitarian logistics. Journal of Operations Management, v. 30, n. 7-8, p.494-506, nov. 2012.

KEEN, P.K.; ELLEDGE M.G.; NOLAN C.W.; KIMMEY J.L. Foreign disaster response: joint task force - Haiti observations. Military Review, v. XC, n. 6, p. 85-96, nov.-dez. 2010.

KOBIYAMA, M.; MENDONÇA, M.; MORENO, D.A.; MARCELINO, I.P.; MARCELINO, E.V.; GONÇALVES, E.F.; BRAZETTI, L.P.; GOERL, R.F.; MOLLERI, G.S.; RUDORFF, F.M. Prevenção de desastres naturais: conceitos básicos. Curitib: Organic Trading, 2006. 
KRESS, M. Operational Logistics: The Art and Science of Sustaining Military Operations. Kindle Edition. Massachusetts: Kluwer Academic Publisher, 2002.

JOMINI, A.H. A Arte da Guerra. França, 1836.

LEANING, J.; BRIGGS, S.; CHEN, L.C. (edit.). Humanitarian Crises: The Medical and Public Health Response. Cambridge, MA: Havard University Press, 1999.

LONG, D.C.; WOOD, D.F. The Logistics of Famine Relief. Journal of Business Logistics, v. 16, n. 1, p. 213-229, 1995.

MARCELINO, E.V. Desastres Naturais e Geotecnologias: Conceitos Básicos. Caderno Didático ${ }^{\circ} 1$. Santa Maria, RS: Instituto Nacional de Pesquisas Espaciais (INPE), 2008.

MARINHO, W. C. S. A Coordenação do EMCFA na participação das Forças Armadas no apoio à Defesa Civil. In: Simpósio de Ajuda Humanitária. Recife, PE, mai. 2014. Apresentações. Disponível em: <http://bdex.eb.mil.br/jspui/handle/123456789/228> . Acesso em: 20 fev. 2017.

MELO, D.C.; ALCÂNTARA, R.L.C. A gestão da demanda em cadeias de suprimentos: uma abordagem além da previsão de vendas. Gestão \& Produção, São Carlos, v. 18, n. 4, p. 809-824, 2011.

MORA, P.; BRAIN, I. Chile antes e depois da catástrofe: alguns dados cruciais para analisar os desafios da reconstrução. Gerência de riscos e seguros, ano XXX, n. 116, p. 74-88, $2^{\circ}$ quadr. 2013.

NOVAES, A.G. Logística e gerenciamento da cadeia de distribuição: estratégia, operação e avaliação. Rio de Janeiro: Campus, 2001. 409 p.

NOVAES, A.G. Logística e gerenciamento da cadeia de distribuição: estratégia, operação e avaliação. 3. ed. Rio de Janeiro: Campus, 2007. 400 p.

OLIVEIRA NETTO, S. Emprego das Forças Armadas em ações de Defesa Civil. Jus Navigandi, Teresina, ano 19, n. 3842, 7 jan 2014. Disponível em <https://jus.com.br/artigos/26341>. Acesso em: 14 dez. 2016.

OLORUNTOBA, R. An analysis of the Cyclone Larry emergency relief chain: some key success factors. International Journal of Production Economics, v. 126, n. 1, p. 85-101, jul. 2010.

ORGANIZAÇÃO DAS NAÇÕES UNIDAS (ONU). The United Nations Office for Disaster Risk Reduction. International Strategy for Disaster Reduction: terminology. Genebra: UNISDR, 2009.

ORGANIZACION PANAMERICANA DE LA SALUD (OPAS/OMS). Situation de salud em las américas: indicadores básicos 2009. Washington: OPAS, 2009.

ORGANIZACION PANAMERICANA DE LA SALUD (OPAS/OMS). EI terremoto y tsunami del 27 de febrero em Chile. Cronica y lecciones aprendidas em el sector salud. Santiago, Chile: OPAS, nov. 2010. 
PALLARDY, R. Haiti earthquake of 2010. Encyclopaedia Britannica, ago. 2016. Disponível em <www.britannica.com/event/Haiti-earthquake-of-2010>. Acesso em: 20 fev. 2017.

PALLARDY, R.; RAFFERTY, J.P. Chile earthquake of 2010. Encyclopaedia Britannica, mai. 2016. Disponível em: <https://www.britannica.com/event/Chileearthquake-of-2010 $\geq$. Acesso em: 20 nov. 2016.

PAN AMERICAN HEALTH ORGANIZATION (PAHO). Health response to the earthquake in Haiti January 2010: Lessons to be learned for the next massive sudden onset disaster. Washington: PAHO; 2011.

PHILLIPS, M. The role of the military in international disaster relief activities. In: International Symposium on Security Affairs 2011. Presentations. Tóquio, nov. 2011. Disponível em: <http://www.nids.mod.go.jp/english/event/symposium/e2011.html>. Acesso em: 22 fev. 2017.

REINO UNIDO. Ministry of Defense. Global Strategic Trends out to 2045. 5 ed. $\quad 2014 . \quad$ ago. Disponível em: $<$ https://www.gov.uk/government/publications/global-strategic-trends-out-to2045>. Acesso em: 18 fev. 2017.

SILVEIRA, D.T.; CÓRDOVA, F.P. A pesquisa científica. In: SILVEIRA, D.T.; GERHARDT, T.E. (Org.). Métodos de Pesquisa. Porto Alegre: UAB/UFRGS, SEAD/UFRGS, 2009. p. 31-42.

SUTTER, C.; KING, A.M. Vivendo sobre escombros: qualidade de vida no Haiti pós-terremoto. Salud \& Sociedad, v. 3, n. 3, p. 235-249, set.-dez. 2012.

UNITED STATES GEOLOGICAL SURVEY (USGS). Report on the 2010 Chilean earthquake and tsunami response. Reston, VA: U.S. Geological Survey, 2011.

UNITED STATES GEOLOGICAL SURVEY (USGS). Ring of fire. Earthquake Glossary, 2016. Disponível em: <https://earthquake.usgs.gov/learn/glossary/>. Acesso em: 16 nov. 2016.

VAN WASSENHOVE, L.N. Humanitarian Aid Logistics: Supply Chain Management in High Gear. Journal of the Operational Research Society, v. 57, n. 5, p. 475-489, mai. 2006.

VARELLA, L.; MACIEL NETO, T,; GONÇALVES, M.B. Logística Militar X Logística Humanitária: Conceitos, Relações e Operações das Forças Armadas Brasileiras. In XXVII Congresso de Pesquisa e Ensino em Transporte. ANPET, Belém, PA. 2013.

VILELA, F.F. O emprego da Marinha do Brasil na ajuda humanitária: capacidades e limitações. Rio de Janeiro, 2015. Monografia - Escola de Guerra Naval (EGN).

WEEKS, M. Organizing for disaster: Lessons from the military. Business Horizons, v. 50, n. 6, p. 479-489, nov.-dec. 2007. 
YANEZ, R. O novo papel das forças armadas chilenas em caso de desastres naturais. Rio de Janeiro, 2012. Monografia - Escola de Guerra Naval (EGN).

YIN, R.K. Case study research: design and methods. $5^{\mathrm{a}}$ ed., Sage Publications, 2013. 